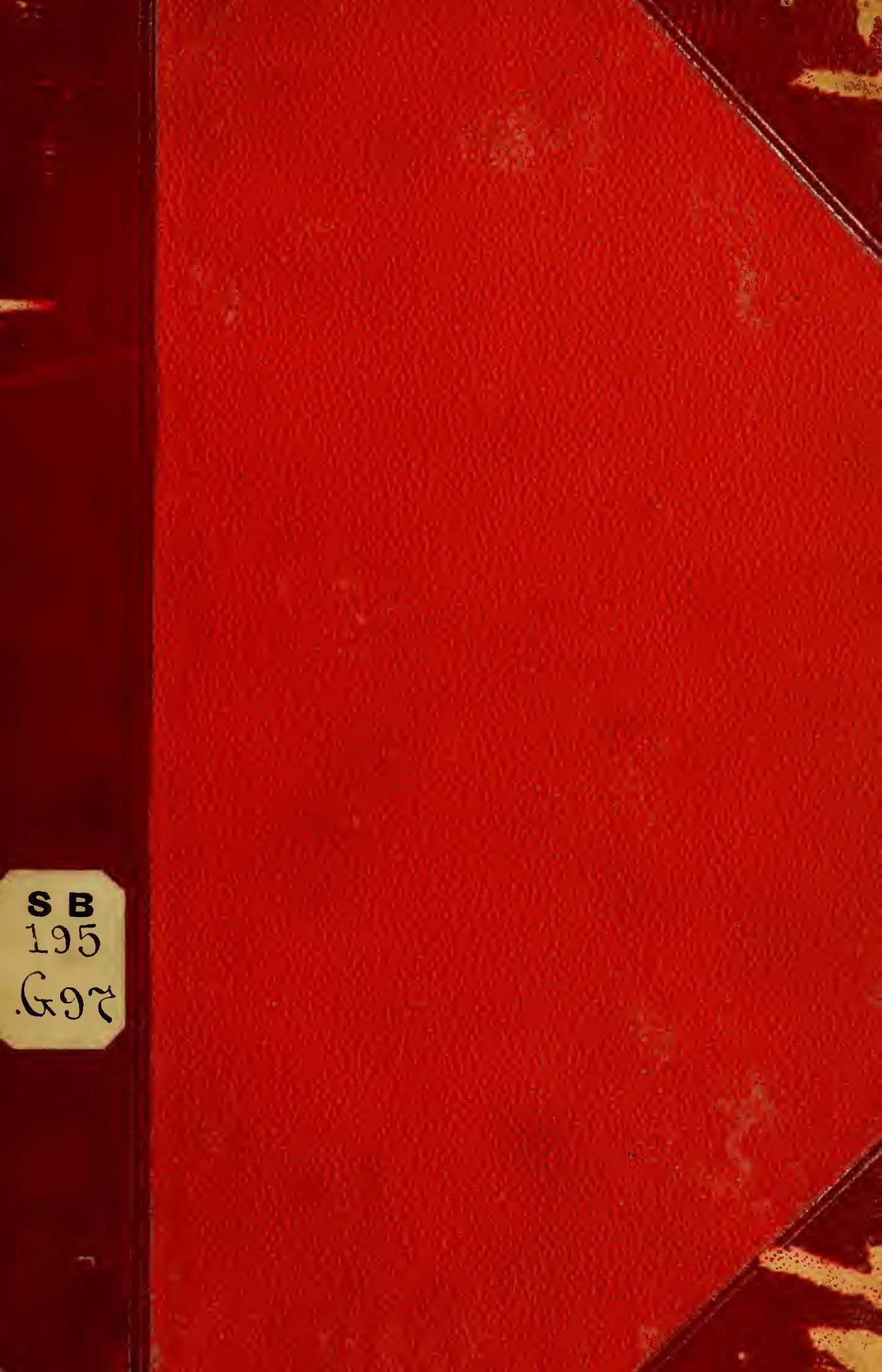




\section{LIBRARY OF CONGRESS.

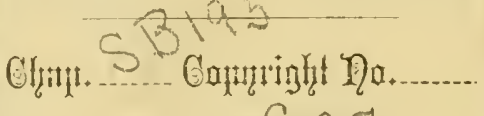 Shelf. Gar UNITED STATES OF AMERICA.}









\section{SILOS, SILAGE,}

AxD

\section{CATTLE FEEDING.}

A Practical Treatise on Growinọ̣ and Harvestinọ Silaṣe Crops, Buildinọ Silos and Feeding̣ Cattle.

B Y

$$
\text { F. A. GULLEY, N. Sc. }
$$

Author of "First Lessons in Hgriculture;" Director of the Texas Agricultural Experiment Station.

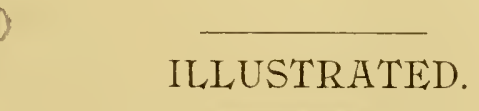

DALLAS, TEXAS:

TEXAS FARM AND RANCH PUBLISHING CO. 1890 . 凹 
Entered according to Act of Congress in the year 1S90, by TEXAS FARM And Ranch Publishing Co., in the office of the Librarian of Congress at Washington, D.C 


\section{CONTENTS.}

PAGE

Chapter I-Ensilage of Forage Crops . . . . . . 5

Chapter II-Silage vs. Dry Forage . . . . . . . . . . 9

Chapter III-Silage Crops and How to Grow Them . . I4

Chapter IV-Varieties of Corn and Sorghumı.... . 21

Chapter V-Harresting the Crop . . . . . . 26

Chapter VI-The Silo.... . . . . . . . . 34

Chapter VII-Silage as a Feed Stuff . . . . . . . . . 45

Chapter VIII-Cattle Feeding. . . . . . . . . 49

Chapter IX-Cattle Feeding Shed ........ 59

\section{ILLUSTRATIONS.}

PAGE.

Bedding Land-Single and Double Beds....... . I7

Corn Knife . . . . . . . . . . . . . . . . . . . 29

Cotton Seed Boiler.... . . . . . . . $57,5^{8}$

Doors for Silo. . . . . . . . . . . . . 37

Framework of Silo. . . . . . . . . . . . 37

Plan of Cheap Silo. . . . . . . . . . . . 4 I

Plan of Double Silo. . . . . . . . . . . . 36

Plan of Corner of Silo. . . . . . . . . . . . 42

Plan of Cattle-Feeding Shed . . . . . . . . . . 55-6-7

Rack for Hauling Forage. . . . . . . . . 30, $3 \mathrm{I}$

Root Derelopment of Corn . . . . . . . . . 20

Snoothing Harrow . . . . . . . . . . . . . 20 



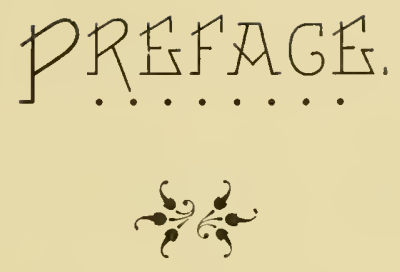

$\Upsilon^{\mathrm{HE}}$ following pages have been written partly at the solicitation of the Texas Farm and Ranch Publishing Company, and partly to answer more fully the many requests received for information in regard to Silos and the Ensilage of forage plants.

The greater part of the literature on the subject is based on the use of Silage in the Northern States.

Believing, as I do, that the climate and soil of the Southern half of the country is better adapted to the growth and ensilage of forage crops than the more Northern States, and that cattle food may here be produced at less cost, this book has been written with a desire to encourage a careful study of the most economical method of converting the products of our fertile soil into beef and milk.

F. A. GULLEY.

College Station, Texas, Feb., 1890. 



\section{SILOS, ENSILAGE AND CATTLE FEEDING.}

\section{CHAPTER I.}

Ensilage of Forage Crops.

[T:TORING forage crops in silos has been practiced in Europe So. for some years, but it is comparatively new in this country, dating back not more than fifteen years.

"The many favorable reports in regard to the ensilage of maize by the farmers of France led me, in 1875, to make experiments in the ensilage of corn fodder, in two silos, i 2 feet long and 6 feet wide, and with two similar silos of broom corn seed, with the most satisfactory results.

"Mr. Francis Morris, of Maryland, made a silo in 1876 , and the results of his experience were published in 1877 . A number of silos were built in the United States within the next three or four years, nearly all of which were widely advertised in the agricultural press. After this time the practice was rapidly extended, and silos are now found in almost every State and Territory.

"In July, I882, the Department of Agriculture at Washington published a report on ensilage, which contained statements of the experience of 9I persons, distributed as follows: Maine, 4; New Hampshire, 2; Vermont, II ; Massachusetts, 28; Rhode Island, I; Connecticut, 5; New York, 21; New Jersey, 5; Maryland, 2; Virginia, 2; Kentucky, I; Tennessee, I; North Carolina, I; Wisconsin, 3; Iowa, 1; Nebraska, I; Canada, 2. But even at that time there were undoubtedly many silos in the country that were not included in this enumeration. The capacity of the silos reported varies from about 8 to 500 tons each." **

A small silo filled with silage was exhibited at the Atlanta Exposition in r88 r After this, a silo built by the author at the Mississippi Agricultural College in 1882 was the first one fairly tested in the Gulf States, so far as we can learn.

*Silos, Ensilage and Silage, ISS9, M. Miles, M. D., F. R., M. S., pp. 37-S. 
As some confusion exists as to the proper name of the contents of the silo and the meaning of the word "ensilage," we wish to state that we have adopted the following definition, from Dr. Miles :

"For the convenience of those not familiar with these terms, the following definitions may be given, as representing the present nonenclature of the subject:

"Silo-A closed pit, or reservoir, in which either dry grain or green fodder is preserved.

"Silage-The green fodder preserved in a silo.

"Ensilage-The process of preserving green fodder in silos." *

It is well known that when green and fresh plants of any kind are piled in a heap, in moderately warm weather, the heap heats and soon begins to decay, and forms a rotten, disagreeable mass.

Formerly it was believed the decay was the result of chemical decomposition, brought on by the action of the oxygen of the atmosphere, which might be prevented by exclusion of the air, as in sealing up fruit in air-tight cans; but it is now held that the fermentation is caused and the decomposition hastened by the growth of minute organisms floating in the atmosphere; which find in the moist mass of succulent matter the food for rapid increase and growth.

A low temperature renders the organisms inactive, and a high temperature destroys them, as in scalding fruit before it is canned.

The investigations of Pasteur and other experimenters show that if the air is filtered before it is allowed to come in contact with a substance that, under ordinary conditions, sets up putrefactive decomposition, the substance will remain in the same condition until air not filtered reaches it.

All who have had much experience in the ensilage of green crops know that sometimes the silage does not keep well; it comes ont quite sour, and still again, a portion of it will be quite rotten and unfit for food, even with careful management.

What causes the changes that take place in ensilaged green forage-how much of it is due to bacterial and how much to chemical action is not yet fully understood 
In the early practice of ensilage of forage in this country the French system of rapid filling of the silo and use of heavy weights to compress the silage, recommended by Goffart, was followed, and the result was silage with a sour taste.

We believe Dr. Miles was the first to recommerd filling the silo slowly and without tramping, so as to allow the forage put in each day time to get quite warm, and thus destroy the bacteria that causes the acid fermentation.

Slow filling, or filling in two or three feet every other day, to allow each layer to heat, has been quite largely adopted, and we now have many reports of "sweet" silage in place of sour silage. The improvement, however, seems not to be due to slow filling entirely, as many persons fill their silos rapidly and make as sweet silage as is secured by slow filling.

It has been noticed that the condition of the crop when ensilaged has a good deal to do with the acidity of the silage. Corn cut quite green, $i . e$, at the tasseling stage or earlier, is apt to make sour silage, while corn allowed to become nearly ripe, and not put up in a too succulent condition, is found to make sweet silage, with either slow or rapid filling.

In our own experience we have gotten best results by allowing the corn to grow until the kernels are hard, then cutting and throwing in armfuls on the ground and letting it lie from twelve to twenty-four hours to wilt, when the stalks and leaves were green at this stage of growth, before filling into the silo. If the forage is not green we cut and fill at once.

Handled in this way, we have made "sweet" silage, filling in two feet every second and every third day, and we have secured equally good results by filling an 8o-ton silo in four days.

It is often stated that the crop will not keep well if put in while we'c with dew or with rain. In 1884 , as an experiment, we filled a 50 -ton silo, during a rainy spell, with corn that was dripping wet. A considerable quantity of liquid ran ont from the bottom of the silo, and when opened the silage was quite sour, but otherwise seemed to have kept as well as the corn put up dry. The cattle ate the sour silage with as much relish, and seemed to thrive nearly as well as on forage put up in dry weather. We would not, however, recommend ensilaging wet forage when it can be avoided.

We have several times put in several tons of over-ripe, or nearly cured, corn, and sorghum, sometimes in the middle, and 
again near the bottom or top of the silo, and in nearly every case had it come out more or less injured by "dry rot" and mouldy.

We have had corn, sorghum, both sweet and non-saccharine, red clover, and cow peas keep well, and again, all but the corn and sweet sorghum fail to keep, under as near similar conditions as we could provide. We have also had sorghum, and sugar cane bagasse left in a pile by the mill, exposed to the winter rains and tramped by stock, keep for months so that the cattle would eat it with relish, all but the upper part, while the same bagasse, taken fresh from the mill and packed into the silo, spoiled entirely with the "dry rot."

The non-saccharine sorghums have not kept as well in our experience as the sweet varieties, nor as well as corn.

It is evident that there is much yet to be learned in reference to the ensilage of forage crops to preserve them in the best condition for food, and to make different crops keep equally well.

Some silage, at the top of the pit, in the corners and sometimes near the walls, will spoil, but this loss may now be reduced to small proportions with careful management. We have practically eliminated the loss in the corners of the silo by the plan of building shown in Fig. 9. With well matured corn, the loss next to the walls is not serious in wooden silos, although with stone and cement walls considerable loss is reported in the colder portions of the country.

With us, the wooden silo, with walls lathed and plastered with cement mortar, gives the same result as plank walls. Rotting next to the walls may be prevented by allowing the cut forage to pile up in the centre of the silo when filling, and get warm over night or for one day, and then pitch the heated mass over against the walls, repeating this process day after day, thus getting warm silage piled against the walls and in the corners.

With the corners of the silo cut off, as shown in the plan, Fig. 9, and the mass well tramped next to the walls, but not in the centre of the pits, we have had very little trouble with silage rotting.

With others, we have used both heavy and light weights on the top of the silage, and tarred paper and plank covers, and finally settled on running a lot of old hay, straw or other refuse material through the cutter and elevating with the carrier to spread over the silage a foot and a half or two feet deep after the silage has settled, and the last plan we like best. 
The covering should not be disturbed after it is put on, unless it is to place still more of the same kind on top, or fill up to the roof with hay or straw, or something that will press the covering material down more compact.

We find the space above the silage a good place to store bedding material.

Hay placed on the silage will become musty unless plank and tarred paper are laid between them. We have also used sawdust, and earth with good results. The latter becomes quite dry and may be used as a liquid absorbent under the stock during the winter.

Reports are conflicting in regard to corn and sorghum put into the silo with and without passing them through the feed cutter, some claiming that the uncut fodder keeps best. In our own experience we have found that whole corn and sorghum must be put in very carefully, laid straight and well tramped down to keep well, and at the best it has not kept so well as when run through the cutter. Carelessly thrown in, a large portion spoils, and sorghum has not done so well as corn put up this way.

The heavy labor in filling the silo and the trouble in getting whole stalks ont to feed makes it so much more desirable to run the crop through a cutter and elevate into the silo with a carrier on the cutter, that we would not, in our own work, use the silo without the cutter.

\section{CHAP.TER II.}

Sillage vs. Dry Forage.

COME of the first who practiced ensilage of forage crops in this country, carried away with the novelty of this new departure in agriculture, made very extravagant claims in regard to the value of silage in stock feeding.

The slirewd manufacturers of feed cutters, and horse powers took advantage of and helped on the "boom" by sending out sheets and pamphlets advertising their machinery, containing statements from the most enthusiastic advocates of the system of ensilage.

Remarkable yields of crops per acre and astonishing results 
of feeding silage were reported. The assertion was made that the silo added to the nutriment in the forage, made it more digestible and therefore of much more value than it would be cured dry, as hay The attention of the chemist was called to the subject, but the analysis of silage showed no gronnd on which to base the assertions; in fact, it demonstrated that there was an actual loss, as a portion of the forage stored in the silo is consumed in the process of fermentation.

The farmers and dairymen who had tested silage in feeding cattle and found it a valuable addition to their feedstuffs, were led to discredit the opinions of the chemists, believing them to be in conflict with their practical tests, and for a time many of our agricultural papers were filled with articles criticizing the work of the chemists, denouncing their determinations as theoretical conclusions, of 110 value when compared with the results obtained by practical men.

In the Fall and Winter of I88 I a carefully conducted test of the comparative merits of silage and dry fodder was made at the New Jersey Experimental Station and reported in Bulletin No. 19, February, I882. One half of a crop of corn was shocked in the field, the other half cut $u p$ fine and placed in a silo The fodder and silage were fed to cows giving milk, the corn fodder cut up fine. The results in yield of nilk were so nearly alike that one may be classed as equal to the other in food value. Bulletins Nos. I 5 and 19 of Wisconsin show nearly the same results in production of milk, but the churning of the milk showed that the butter was more perfectly separated from the milk made from silage. Tests at the New York Experiment Station also showed a better separation in the process of butter making from cows fed on silage.

We are forced to admit that carefully conducted tests in feeding silage show that the ensilage of some of our forage crops does not make then of more value for feeding than they would be if cured dry under the best conditions, although this may not agree with the opinions of the practical man.

"Experiments have been made to test the relative feeding value of dry fodder corn and the same fodder ensilaged, with results that are not decisive, as the problen is an exceedingly complex one, that cannot be solved by a few simple tests with a small number of animals." "*k

* silos, Ensilage and Silage, by M. Miles, p. 93. 
It should be borne in mind, however, that while the acceptable evidence to the present time shows that a given quantity of forage cured dry, as hay, may, under the best conditions, be of as much value as the same made into silage, it does not follow that the ensilage of certain crops may not make them of more value for feeding than to cure them dry, as practised on the average farm, or on the best managed farms.

Crops that are difficult if not impossible to cure dry, under ordinary conditions, without a loss of from 25 to 50 per cent or more, may be stored in the silo with safety. So that as a practical method of putting up forage, the ensilage of certain crops may be of very great advantage on farms where the feeding of live stock plays an important part.

We do not believe it will be found profitable in this country to ensilage forage that may be readily cured as hay-such as the grasses, and even red clover and cow peas if the weather is favorable for drying when they are ready to harvest.

Corn and sorghum are difficult to cure dry in any season without considerable loss, and especially when grown on fertile soil, where the stalks grow large and the crop is heavy.

The experiments at the Wisconsin Experiment Station show that when corn is planted thin enough to make ears, and cured dry, that the larger part of the stalks will be rejected by well fed cattle unless the fodder is run through a cutter, and when cut up the butts of the stalks are not eaten. We have found that cows would waste a large portion of dry sorghum fodder if it was not cut up before feeding. We find this opinion held by all wlio have fed dry corn and sorghum forage.

Admitting that it is necessary to pass corn and sorghum through the feed cutter to secure economical consumption, it is evident that it will require less labor to load the crop at once on the wagon when it is cut, lianl to the cutter direct and run it into the silo and have it stored in safety at one operation, than to shock in the field, tie up, then haul to the stack or barn, and move again to the cutter to prepare it for feeding.

"Hon. Hiram Smith, of Wisconsin, makes the statement that by actual trial he found that a load of corn forage could be run through the feed cutter, elevated more than twenty feet, and deposited in the silo, in seven to eight minutes less tinie than was required to set it up in shocks in the field. '*

*Sitos, Ensilage and Silage, by M. Miles, p.,95. 
In this connection, we refer to a statement of Prof. E. M. Shelton, Professor of Agriculture and Director of the Kansas Experiment Station, in which he refers to the difficulty of growing corn fur both grain and forage as practiced in many of the Northern States: *'But here again we encounter a serious difficulty in the fact that we are compelled, to save the fodder in good condition, to harvest it early in August, when, in the present arrangement of farm work, it is difficult if not impossible to get the time from other duties in which to do the work; and corn cut up at this early season, as every farmer will recognize, unless at once husked and the fodder stacked or otherwise housed, becomes almost entirely worthless from natural causes long before the feeding season has arrived."

Prof. Shelton's experience agrees with our own in Mississippi and in Texas, where the corn crop matures in june and must be kept five or six months before feeding.

Another advantage of silage over dry fodder is that it may be used as an appetizer to secure the consumption of hay that would be rejected if fed alone. We have found that old hay, straw, and even weeds, nay be cut up fine and mixed with silage and the cattle would eat it readily. Fed with some concentrated food, inferor, trashy hay may give good results if the cattle can be induced to eat it. Since we have used silage we have been troubled to find anything in the plant line poor enough to use for bediding.

Cattle are fond of good silage, taking it in preference to dry forage, or even grain.

In our feeding experiments in Mississippi, $\dagger$ steers that were fed all the silage and cottonseed meal they would eat, with good hay fed by itself, consumed less than one pound of hay per day. At the 'Texas Experiment Station last winter, not above two pounds of hay per head per day was eaten when the cattle were red as much silage as they would consume.

"After one of my cows had had silage for weeks, and no hay, I tried giving her at the usual feed time some very nice, bright, green hay, and silage side by side. She ignored the hay and commenced upon the silage as if ravenous with hunger. The hay

\footnotetext{
*The Industrialist, A pril 6. ISSg.

tA, and M. College Report No. 3,1885 .
} 
was then replaced with some ground oats, and corn mixed. To our surprise, the grain was left undisturbed till the silage was all gone." **

It has been stated by some farmers that their cattle preferred dry corn fodder to silage, but the evidence is so overwhelmingly against this assertion that we are inclined to believe that when such has been the case a good quality of silage was not used in the comparison.

How much influence palatableness has on digestion, cannot be determined. That it is of importance in the lower animals, as well as in man, can hardly be questioned.

f'The form in which a given food is supplied to animals, and even its palatableness, may have a more decided influence in determining its nutritive value than slight differences in chemical composition. The same food may give different results when fed to different animals, and the benefit derived from it by the same may vary widely at different limes, so that extreme cantion should be exercised in interpreting the results of feeding experiments, and in the generalization based upon them."

It is essential to have the animal eat as much as possible in feeding to fatten, and in this respect silage seens to have a decided advantage over dry forage.

The succulent condition of silage is no doubt of value. Stock feeders are agreed that cattle fed on silage have a more thrifty appearance than when fed on dry forage alone. The hair becomes smooth, the bowels act promptly, and there is less liability to fever and constipation. "It is generally adnitted that some form of succulent food is a valuable addition to the ordinary winter rations of live stock, and the question arises as to the best and cheapest method of providing it. The English farmer looks upon his root crop as an indispensable adjunct of his food supply for farm stock, but in this country, for many reasons that need not be stated, the raising of root crops will not, in all probability, be extensively practised. The steaming of feed of all kinds has been urged as the true solution of the problem, but this method has failed to gain the approval of a large majority of farmers, and where it has been tried on a considerable scale, it is apparently on the decine." $\ddagger$

* silo and silage, by A. J. Cook, p. 7.

tSilos, Ensilage and Silage, by M. Miles, p 93.

†Silos, Ensilage and Silage, by M. Miles, p. 94 . 
"Silage is much more digestible than dried food, and thus the beef animal fed on it looks much more sleek and lays on fat faster, the milk cow gives more and better milk; all animals cattle, horses, sheep and hogs-thrive upon it, and are more thrifty and healthy, because it ministers to their every need. Such men as F. D. Curtis, E. A. Powell and J. S. Woodward, of New York; J. Gould, of Ohio; and H. Smith, of Wisconsin, dairymen of the highest intelligence, who understand their business from $\mathrm{A}$ to $Z$, all unie in the assertion that it adds decidedly to both the quantity and quality of the milk. I recently saw in Secretary J. S. Woodward's barns, at Lockport, N. Y., a large herd of cattle which had been carefully divided in the fall into two lots, as uniform in condition as it was possible to make them. Each lot had been crowded to the utmost by free use of mixed grains. But one lot has had silage and the other the best of clover hay. Otherwise the treatment has been the same. This was a wonderful revelation. The cattle fed silage, in condition, both as to sleekness and fat, were surprisingly superior to the others. I said if all were turned into a yard I believed I could select all of the silage-ted animals with hardly a mistake. ' The other gentlemen present-Col. F. D Curtis, Hon. Seth Fenner and Prof. E. F. Ladd-were as sanguine of the same ability as was I."'*

*Silo and Silage, by Prof. A. J. Cook, pp. 6 and 7.

\section{CHAPTER III.}

Silage Crops and How to Grow Them.

EARLY all forage crops may be preserved in the silo, but, as Nom has been remarked, the special value of the system lies in ensilaging crops not readily cured as hay. Corn is the crop of all others in the United States where corn grows well, but in the dryer portions of the country and on the thin soils of the Southern States, sorghum grows with more certainty and yields more feedstuff to the acre than corn.

On good corn land - such as may be made to yield thirty to fifty bushels of corn to the acre-I prefer corn, even in the South. It may be grown with less labor, and I think has some advantage in keeping qualities. 
In feeding value there is probably no great difference between corn and sorghum silage. So far as we can learn, no conclusive experiments have been made to determine this point. There seems to be as much or more variation in both corn silage and sorghum silage, due to different varieties and methods of growing and time of havesting, as there is between the two plants.

The cultivation of the two plants is quite similar, except that sorghum is more tropical in its nature and will not bear as early planting on cold, heavy soil as corn. Sorghnm does not germinate as quickly as corn, and it does not grow off so rapidly and keep ahead of the grass and weeds. It requires, therefore, more labor on such land.

Corn for silage is planted and worked very similar to the corn grown for the grain, but it may stand thicker on the ground. We do not agree with those who recommend planting the same for either purpose, as we believe that more nutritive matter will be produced where the stand is too thick to yield the largest amount of corn alone.

In the Northern States corn has a dwarf habit of growth, and we find but four to six square feet of ground given to each stalk. As we go south corn grows higher, the stalks grow larger, and from ten to twenty or more square feet are given to each stalk.

The poorer the land the more room is required to enable the stalks to ear well. That the distance between stalks is not a question of latitude altogether, I have demonstrated in Mississippi. On land that would, under the best ordinary cultivation, produce forty bushels of corm, and where twelve square feet of land was thought to be the least space a stalk should occupy to ear well, I reduced the area to six square feet, and, by applying a moderate amount of fertilizer and giving good cultivation, increased the yield to seventy-five bushels of sonnd corn to the acre.

Referring to growing corn for the grain and for forage, Prof. Shelton, of Kansas, says: "It is perfectly clear to me that we must raise corn for corn, with no thought of fodder, and corn again which has no higher purpose than the production of fodder. We must, iu short, have two cornfields on every farm, receiving radically different treatment, to correspond with the different purposes for which they are cultivated."* 
There is a limit, however, to thick planting. Sown broadcast, corn will yield only one-half to two-thirds as much weight of crop as when planted in drills, and it will be of poorer quality. An experiment made at Cornell University Station demonstrates this point, and it agrees with the experience of farmers generally, who have tested both ways of planting.*

From our own experience, and from what we can gather from others, we would say, do not plant so thick that the corn will not make small ears on at least half of the stalks. Some varieties will ear with stalks nearer than others, and all varieties we have ever tried will stand thicker and make more ears on well fertilized land than they will on poor soil.

In growing corn for silage, the object is not simply weight of crop to the acre, but quantity of nutriment matter, and this, it is believed, may be best secured by planting as suggested, varying the thickness of the stand to conform to the varicty and to the fertility of the soil. In Texas and Mississippi, on land that will produce from twenty-five to thirty bushels of corn, we prefer to plant in rows four feet apart and have stalks average ten to twelve inches apart in the row, with large varieties of corn. Sorghum with rows the same, we would have the stalks not more ihan three or four inches apart.

More weight of crop to the acre may be secured from thicker planting, but at the expense of quality.

The method of planting will vary with the character of the soil. On loose, well drained soil we prefer to break broadcast and plant level. On dry, clean land, or after cotton on dry land, listing will save labor and time, and give as good results in crop.

The method of listing in planting corn is very popular on the dry soils of some of the Western States, and special implements are in tise for the work. It consists in drilling the seed at the bottom of deep furrows run off at the usual distance of the rows, on otherwise unplowed land, and breaking out the middles later. On heavy and not thoroughly drained land, where heavy spring rains prevail, we would plant in beds to insure a stand, and secure quick germination.

Either single or double beds may be used, but the latter is preferred, as it permits more thorough breaking in throwing up the

*Growing Corn for Fodder and Ensilage, Bulletin No. 4, ISSS. 


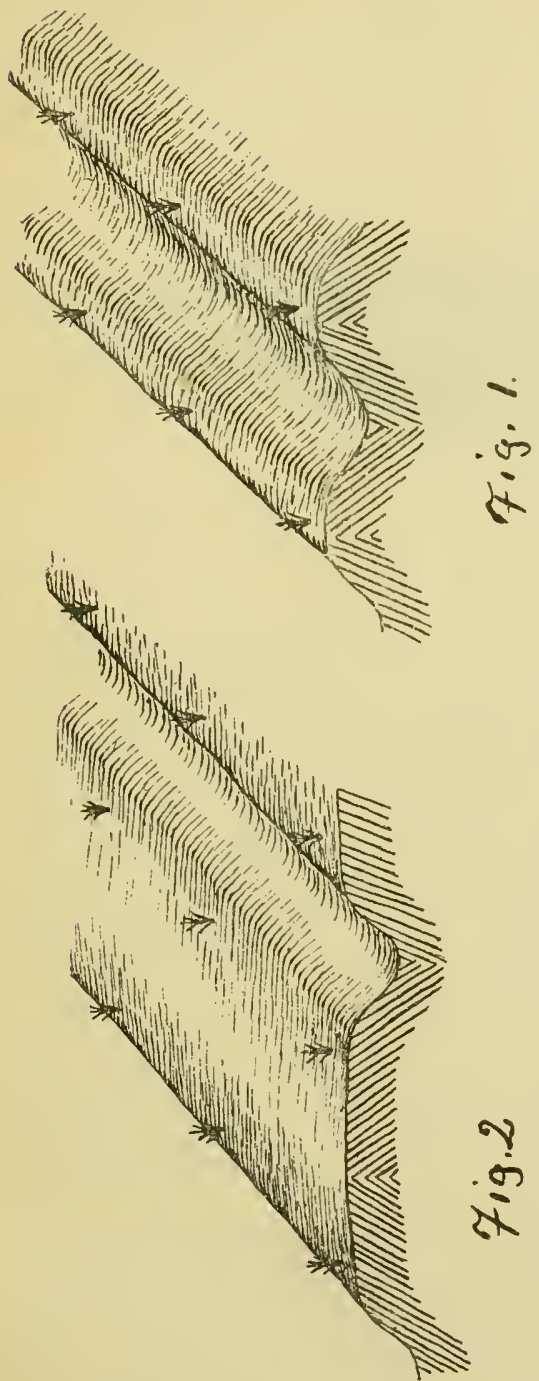

beds, and in the double beds seeds of weeds in the soil are thrown in between the rows where they may be destroyed with the cultivator after germination, instead of under the rows, where they must be cleaned out by hand labor.

Figure I shows the single beds. The soil is turned up, as shown by the shaded lines,. and the seeds of weeds in the land are left under the rows and in the best condition to grow.

Figure 2 shows double beds where the weed seeds are thrown together between the rows, while under the rows the seeds are buried at the bottom of the furrows, and the crop will have sufficient time to get well started off before the weeds come up.

The furrow by the side of each row dries and warms the soil around the seed nearly equal to the single bed, and the soil is left in better condition for broadcast cultivation.

After throwing up the beds with the plow they should be well harrowed to break up the clods and compress the soil.

Figure 3 shows a home-made implement that will do good work after the harrow, in preparing the seed bed for planting. It is simply a stick of timber, tent to twelve inches square, and eight feet long, rigged up as shown in the cut. Only the front and bottom sides of the log need squaring. 


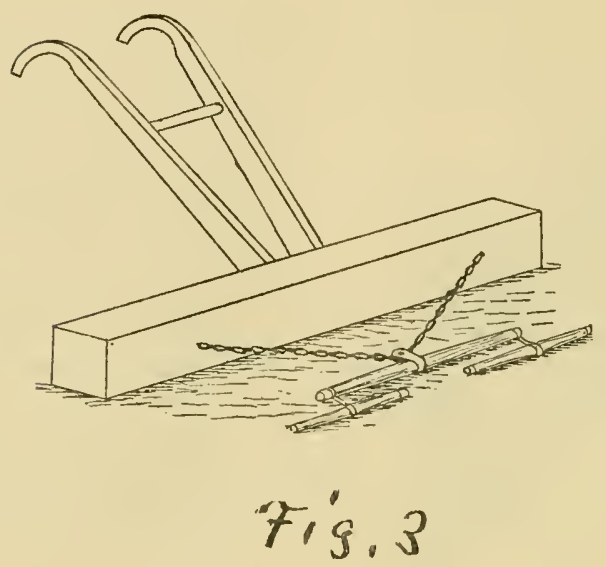

Whatever method of preparation is adopted, the seed should be planted on the freshly prepared land while the soil is still moist, to secure germination before the weeds start.

Corn may be planted by hand in an open furrow and covered with another furrow, but so much time is saved by using a planter, and the seed is so much more evenly distributed, that we would recommend using some one of the many planters now on the market. A common grain drill with all of the spouts but two plugged up does very good work, and may be used on the double beds described, and plant two rows at a time.

The old saying, " $\Lambda$ crop well planted is half worked," holds true with corn. It pays to have the ground well plowed, thoroughly harrowed and made fine and compact before the seed is put in. Early planting is desirable in the Southern States, but not at the cost of poor preparation.

For some years we have had occasion nearly every spring to break up and replant patches of early planted corn where the worms, wet weather or other causes have made a defective stand, and in nearly every case the part replanted has made a better crop than that planted two or three weeks earlier, and with less work to keep clean.

The better growth is due to the extra plowing and better condition of the soil trom the double preparation.

A day or two after planting the ground should be harrowed broadcast, lengthwise or crosswise, with a large framed but light 
harrow, ${ }^{*}$ having small teeth slanting backwards; again when the corn is coming up, and still again when it is three to four inches high. The Thomas smoothing harrow (Fig. 4) is designed espe-

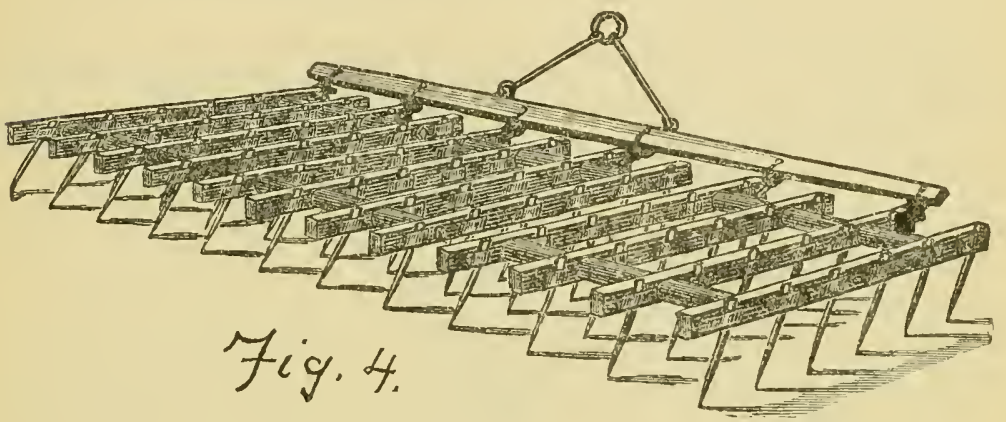

cially for this work, and we consider it indispensable to grow corn at the least cost. With this harrow fifteen to twenty acres may be gone over in a day. The grass and weeds may be kept down and the soil loosened on the surface until the corn is large enough to cultivate; then use a one-horse cultivator that works the entire space between the rows at one bout, without "barring off," and breaking out the middles, as is practiced in many places, or the two-horse implement that finishes the row at one time.

The early cultivation of corn may be deep, but it is of no advantage if the land is well prepared before planting. After corn is one and a half to two feet high deep cultivation seriously injures the crop. Figure 5 gives an idea of the root development of corn at this stage of growtl. The upper roots are the principal feeders, and deep cultivation tears them off and cuts down the supply of plant food at the time most needed. A narrow bladed, long winged sweep, that will cut not more than two inches deep, is the best implement we have used for the late working.

Corn and sorghum are two crops that may be grown with a great deal of certainty in all of the southern half of the countrycorn on the richer and moist lands, sorghum in localities where summer drouths prevail and on the poorer soils. 
With good preparation of the soil before planting, if it is not in good and clean condition, and shallow cultivation often enough to prevent the surface from crusting over, one or the other of these two crops is almost certain to make a fair yield in any season, and

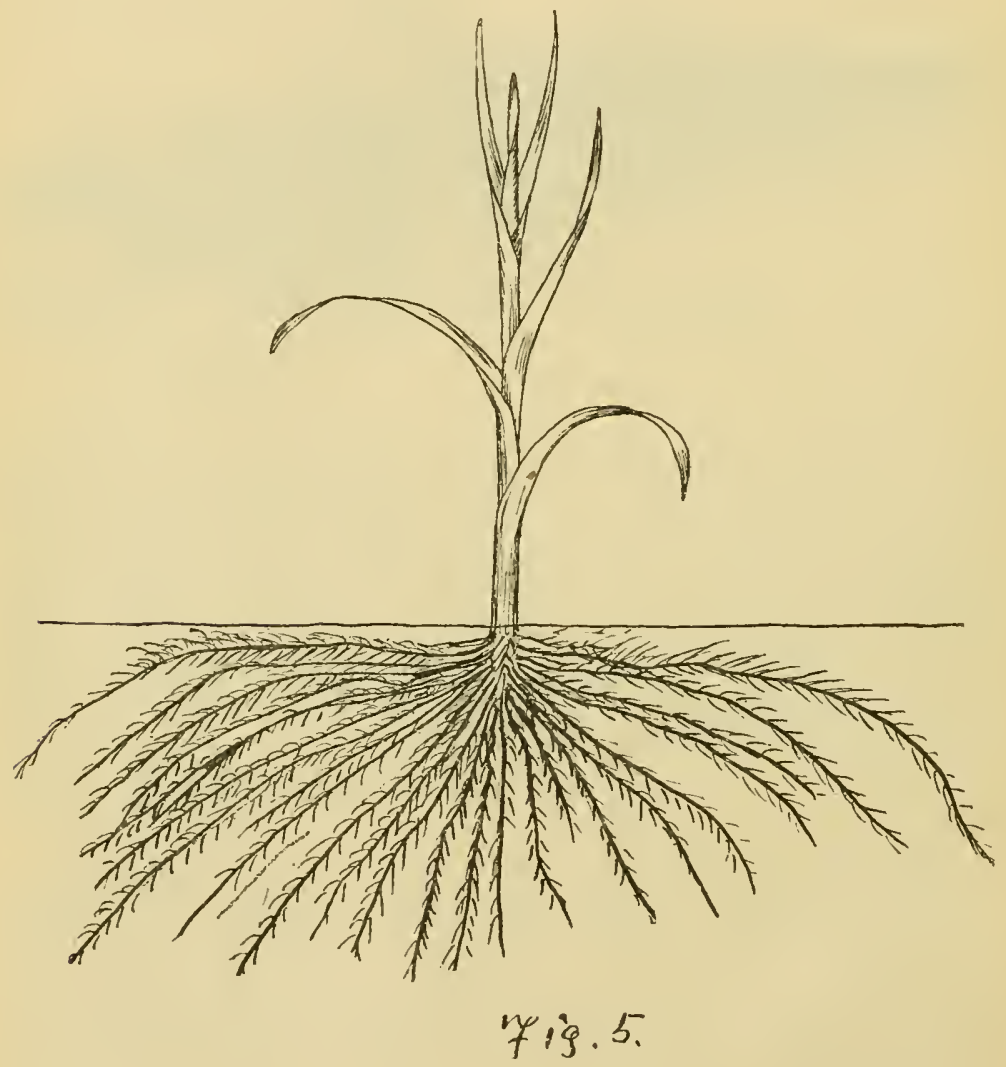

produce more feedstuff to the acre than can be gotten from any any other crop. The safe storage of these crops in the silo may also be counted on, which is not true of making hay, as good weather is one of the essentials in harvesting red clover, cow peas and the coarser grasses when cured in the dry form. 


\section{CHAPTER IV.}

\section{VARIETIFS OF CORN AND SORGHUM.}

THE best variety of corn for silage is one that will grow large, have plenty of leaves, and make ears when the stalks are near together. Large size of the stalks is not objectionable, as they are cut into small pieces and become softened in the silo, and will be readily eaten.

For dry corn fodder the small-stalked varieties and the sweet corns are no doubt best, but as these will not yield so much, and the forage contains little if any more food material in proportion to weight after passing through the silo, they are not to be recommended for silage in the Southern States, and they are being discarded at the North.

We have planted the large varieties of Northeru sweet corn several times but have never been able to get more than one-half the yield produced by varieties of Southern field corn.

What effect planting the most prolific varieties of sweet corn for several years would have, we are not prepared to say, but it has been conclusively shown that northerin sweet corn is not equal in value to common field corn in the Southern States for silage.

While speaking of corn, we wish to call attention to the fact that sonthern varieties of corn contain more nutriment in proportion to weight than northern corn. The celebrated B. \& W. corn, so largely grown in the Central and some of the Northern States, for silage, on account of its large yield, is simply a white native field corn of Virginia.

A number of tests have been made to compare southern with northern corn at the North, and when the warm season has been long enough to mature the southern corn, it has shown a larger amount of food element than the northern corn. Where it has not sufficiently matured it has not been of equal value.

We extract the following from Wisconsin Experiment Station Bulletin No. 19. April, I889.

Nine rarieties of corn were planted and handled in the same way, and cut September 5 , before the large southern varieties were fully matured. 
Table Showing the IVeight of Green Fodder, Dry Matter, Sugar and Protein per Acre:

\begin{tabular}{|c|c|c|c|c|c|}
\hline VARIETIES. & $\stackrel{0}{\tilde{\sigma}}$ & 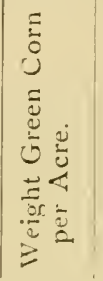 & 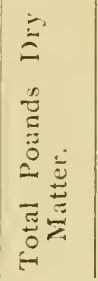 & 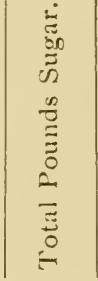 & 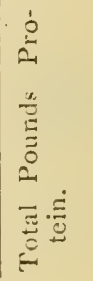 \\
\hline 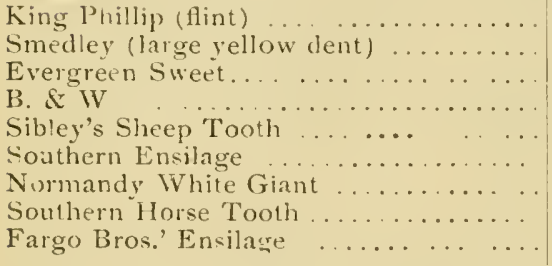 & $\begin{array}{lr}\text { Sept } & .5 \\
.6 & 5 \\
\because & 5 \\
. & 5 \\
. & 5 \\
\therefore & 5 \\
\because & 5 \\
\because & 5\end{array}$ & $\begin{array}{l}26.200 \\
33.5719 \\
22.69 \\
39,500 \\
31.490 \\
43.700 \\
37.390 \\
12,060 \\
39590\end{array}$ & $\begin{array}{r}8.352 \\
10.160 \\
5.526 \\
9,028 \\
7.785 \\
11.060 \\
9.906 \\
14.070 \\
10.150\end{array}$ & 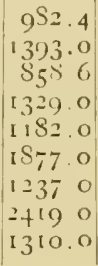 & $\begin{array}{l}572.0 \\
632.3 \\
352.0 \\
47+1 \\
437.5 \\
697.7 \\
625.0 \\
95+7 \\
634.3\end{array}$ \\
\hline
\end{tabular}

"It is seen from the table that at the date of cutting, September 6 , the value of the corn, according to the yield of dry matter, would be in the following order, beginning with the highest:

I. Southern Horse Tooth.

2. Southern Ensilage.

3. Smedley Dent.

4. Normandy White Giant.

5. Fargo Bros.' Eusilage.

6. B. \& W. Ensilage.

7. Sibley's Sheep 'Tooth.

8. King Phillip.

9. Eivergreen Sweet.

"Although the Southern Ensilage is slightly ahead of the Smedley Dent in actual pounds of dry matter produced, yet the greater maturity of the Smedley would place it second in the list, if ranked according to feeding value.

"While the above figures would indicate that the sweet and flint corns were of rather low value for the silo, yet one must take into account the fact that the summer of I 888 was exceptionally favorable to the growth of the southern and adverse to the northern varieties. Another season may reverse the figures, especially 
if it is a cold, rainy one. It is evident from the table that marked difference in composition, as well as yield, exists between the northern and southern corns; also that the weight of green fodder per acre is no indication of the true value of the corn. The large, rank-growing corns (B. \& W. and Fargo Bros.' ensilage), while giving in one case 5000 and in the other 6000 pounds more green fodder to the acre, yet gave no more nutritive matter than the Smedley, a yeliow dent variety of the Pride of the North type, suitable for northern Illinois, but a little too large and late for a general field crop in this vicinity. We must, therefore, in judging of the value of a corn, take into account the time necessary for its maturity. It is necessary that the corn be far advanced toward ripening, and that it be sufficiently matured to have obtained its maximum of growth without having lost its succulence. This condition is obtained when the kernel of the ear is glazed so as not to be easily dented with the nail. Besides having a greater feeding value, corn that has been allowed to mature to the point of glazing has nearly twice as much nutritive matter to the ton as that cut when the ears are just beginning to slow the tassel."

What this showing would have been if the later southern corns had been allowed to reach the stage of maturity of the Smedley dent may be inferred from the quotation, but we have direct evidence to show that they would have been of considerable more value. This point will be referred to later, under the discussion of "When to Harvest."

For several years we have noticed that our cattle would not eat as many pounds of silage per day as cattle consumed in the Northern States, although some of our cattle were brought from the Northern States.

The ration recommended by Northern cattle feeders is from 50 to 75 pounds of silage per day, with grain, and reports are not uncommon of large cows and steers eating as high as Ioo pounds of silage. With a few exceptions 40 pounds of southern-grown silage is the maximum amount we have been able to get steers or cows to eat per day.

Last winter, at the Texas Agricultural Experiment Station, twenty-four Texas steers ranging from soo to 900 pounds, live weight, consumed on the average, each, daily, through the feeding test, less than twenty-two pounds of silage per day, with from one and a half to six pounds of hay and grain or cotton seed, and cottun seed meal, and made an average gain of over two pounds 
per day for eighty-three days. Running orer several years work in our feeding, the average amount of silage consumed per head per day, with grain, is under thirty-five pounds, yet we get as large gain in weight, and yield of milk and butter as is reported from feeding fifty pounds of northern grown silage, and an equivalent amount of grain. $\dagger$

Investigations made by Mr. H. H. Harrington, Chemist of the Texas Station, throw some light on the question of comparative values of northern and southern grown silage.*

Twenty-two analyses were made of the silage during the feeding test of last winter, and to compare with the arerage of these, analyses of silage in Northern States were collated with the following results. $\dagger$

Average Analy'ses of Corn Silage, from Experinent Stations of Massachusetts, Connecticut, Wisconsin, Maryland and Texas:

\begin{tabular}{|c|c|c|c|c|c|c|c|c|}
\hline State. & 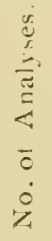 & 离 & 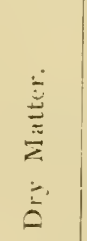 & $\stackrel{\leftrightarrow}{\infty}$ & $\frac{1}{2}$ & 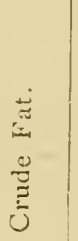 & $\begin{array}{l}\dot{\Xi} \\
\stackrel{\Xi}{0} \\
\stackrel{0}{2}\end{array}$ & 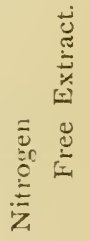 \\
\hline $\begin{array}{l}\text { Massachusetts. ... } \\
\text { Connecticut....... } \\
\text { Wiscon-in.. . . } \\
\text { Maryland ... . . } \\
\text { Texas........ . . . }\end{array}$ & $\begin{array}{r}5 \\
47 \\
1 \\
4 \\
22\end{array}$ & $\begin{array}{ll}79 & 66 \\
8 & 59 \\
77 & 94 \\
79 & 14 \\
64 & 59\end{array}$ & $\begin{array}{ll}20 & 37 \\
19 & 4 \\
22 & 06 \\
20 & 56 \\
35 & 41\end{array}$ & $\begin{array}{ll}\text { I } & 0 \\
1 & 37 \\
\text { I } & 70 \\
1 & 06 \\
2 & .99\end{array}$ & 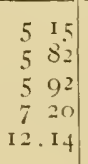 & $\begin{array}{ll}0 & 76 \\
0 & 69 \\
0 & 79 \\
1 & 0 \\
2 & 09\end{array}$ & $\begin{array}{ll}1 & 77 \\
1 & 49 \\
1 & 92 \\
1 & 25 \\
2 & 97\end{array}$ & $\begin{array}{r}\text { I I. } 57 \\
\text { I0.05 } \\
\text { I I. So } \\
\text { S. } 70 \\
\text { I } 5.69\end{array}$ \\
\hline
\end{tabular}

An examination of the above table will show that our silage contains 70 per cent. more dry matter, twice as much crude fibre and fat, more than double the amount of protein, and 50 per cent. more nitrogen free extract than silage grown in the North.

The larger amount of the chemical constituents represents so much more nutritive matter, and, if the results of this investigation are corroborated by further analyses, the reason why cattle make as great return from one pound of southern silage as they

*Bulletin No. 6, Texas Agricultural Experiment Station.

tTexas Expt. Station Bulletin No. 6, pp. 2S, 29, 30. 
do from one and a half to two pounds of northern grown silage is explained.

All authorities agree that the most nutritious silage is made from corn that is nearly matured, and the difficulty that confronts the farmer of the Northern States is to get a prolific variety of corn that will become sufficiently matured before frost. We, of course, have no trouble from early frosts in the South, and can, therefore, let corn mature to any stage we desire.

It seems probable also, from what we can learn of southern varieties of corn grown in the Northern States, that is, from planting sonthern grown seed, that the corn has greater inherent nutritive value than northern varieties where it has opportunity to mature.

It would seem that either onr climate or the long seasons and method of larvesting which has permitted corn to thoroughly ripen on the stalk for years, has developed in it greater food value than is possessed by corn grown in a higher latitude. We refer to the food value of the entire plant-stalk, leaf and ear.

We have dwelt on the value of southern corn simply from a desire to show that the Southeru States possess superior facilities for supplying food for live stock, and especially in the use of the silo.

\section{SORGHUM}

We cannot speak positively in egard to the comparative merits of different varieties of sorghum.

For making hay the smaller varieties, such as the early amber, are preferred. In Kansas, and in some parts of Texas, the non-saccharine sorghums are quite largely planted for forage, and it is claimed that some of them are better adapted to poor land and dry seasons than the sweet sorghums.

Kaffir corn is perhaps the most prolific of all sorghums in seed production, yielding from twenty-five to fifty or more bushels to the acre, but the stalks are hard and woody. After growing quite a number of these sorghums, including Kaffir corn, Doura, chicken corn and some other plants that have been extensively advertised and lauded, such as Pearl millet and 'Teosinte, we have not been so well satisfied with any of them as with the Orange, Honduras and other large, sweet sorghums for silage.

In weight of crop to the acre, possibly Teosinte will surpass the sorghums, but it does not seed before frost, even in Texas, 
and starts off very slowly in the spring, requiring more cultivation than the sorghums. It is a coarse, woody plant, and, in our limited experience, not very palatable to cattle.

From our present knowledge, we are not disposed to recommend any of these new forage plants as being better, or even equal to the sweet sorghums for silage, and of the latter we prefer the large varieties, but would plant thicker than if growing for syrup or for seed alone.

\section{CHAPTER V.}

HaRvesting THE CROP.

HE farmers of the country are skilled in growing and harvesting corn, and their experience will enable them to carry the crop grown for silage to the time it is ready to harvest, for the cultivation to this point is very similar.

The great weight of the crop calls for skillful management in harvesting, or the cost of handling will out balance the gain from the ensilage system.

The proper time to hațvest corn has received some attention from our experiment stations, and as the results obtained from different states agree we may accept then with confidence.

\section{BEST PiRIOD FOR CUTTING.}

"For this test, from a field of Sibley's Pride of the North Corn, planted in hills, fair average hills were selected at different times, cut and weighed, and a sample sent to the laboratory for analysis. At the same time a number of hills sufficient to give a fair average of the yield per acre were also cut and weighed. In this way both the yield per acre and the quality were ascertained. The corn was planted on May 7 th, the first cutting was made on July 24th, at which time the plants were just coming into bloom. The second cutting was made August 8th, when the corn was hardly in the roasting ear condition. The third cutting was made September 3 rd, at which time the majority of the ears were out of the milk, and in one weeks' time the adjoining corn was ready 
to cut and shock. Below are given the results:

\begin{tabular}{|c|c|c|c|c|c|c|c|}
\hline Period. & $\begin{array}{l}\text { Date of } \\
\text { Culting. }\end{array}$ & $\begin{array}{l}\text { Yield lbs } \\
\text { per acre }\end{array}$ & $\begin{array}{c}\text { Percent } \\
\text { Water }\end{array}$ & $\begin{array}{c}\text { Dry Matter } \\
\text { pounds } \\
\text { per acre. }\end{array}$ & $\begin{array}{l}\text { Protein } \\
\text { pounds } \\
\text { per acre. }\end{array}$ & $\begin{array}{l}\text { Fat lbs. } \\
\text { per acre. }\end{array}$ & $\begin{array}{c}\text { Carb-hy- } \\
\text { drates } \\
\text { lbs per acre }\end{array}$ \\
\hline 1. & July 24. & $1 S 762$ & So 34 & 2000 & 2506 & 42. & ${ }^{1} 5436$ \\
\hline I1. & Aug. S. & 24578 & $S_{3} \cdot 57$ & 4039 & 3634 & $S_{1.9}$ & $.33^{2 S} 9$ \\
\hline III. & Sept. 3 . & 27674 . & 7393 & 72142 & $5^{S} 5 \mathrm{~S}$ & 1991 & 6166.7 \\
\hline
\end{tabular}

"It will at once be seen that the most marked difference in the composition of the fodder cut at the different periods consists in the constant and rapid decrease in the amount of water. While the gross yield increased only about 50 per cent from July 24 th to September $3^{r d}$, the amount of dry matter increased more than $35^{\circ}$ per cent.' $*$ *

At the Pennsylvania Experiment Station, with ten varieties of corn, similar results were obtained. We copy weights of two varieties of corn from the report:t

\begin{tabular}{|c|c|c|c|c|}
\hline \multirow[b]{2}{*}{ VARIETY OF CORN. } & \multicolumn{4}{|c|}{ YIEI,D PER ACRE. } \\
\hline & 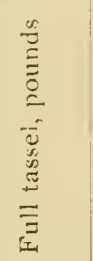 & 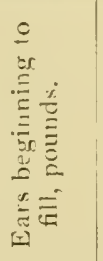 & 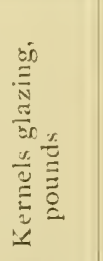 & 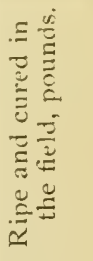 \\
\hline 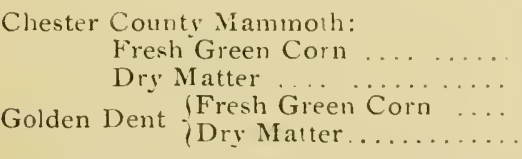 & $\begin{array}{r}26,670 \\
3.392 \\
21.300 \\
2,633\end{array}$ & $\begin{array}{c}32,250 \\
4.33 \\
26.670 \\
3,825\end{array}$ & $\begin{array}{r}32.620 \\
5.690 \\
30.950 \\
5.344\end{array}$ & $\begin{array}{r}15.768 \\
7.3 \mathrm{SI} \\
1.5 .2 \mathrm{So} \\
7.095\end{array}$ \\
\hline
\end{tabular}

In the report referred to, Mr. Caldwell summarizes as follows, referring to the results obtained in Pennsylvania and New York. Letting roo represent the dry matter per acre of corn cut when in tassel, the gain would be shown by the following figures:

\begin{tabular}{c|c|c|c|c}
\hline \hline State. & First Period & Second Period & Third Period & Fourth Period \\
\cline { 1 - 2 } Pennsylvania & 100 & 153 & 212 & 325 \\
New York.... & 100 & 202 & $36 t$ & \\
\hline \hline
\end{tabular}

* Cornell University Experiment Station Bulletin, No. 4, p. $5^{2}$.

†Annual Report, State College Experiment Station, Penn., 1SSS, pp. 2S-9. 
The very marked increase of dry matter after corn tassels shows how much food material is lost in cutting at this stage of growth.

A larger proportion of the dry matter at the first stage may be digested, but if the food is palatable to the animal, so that he will eat it clean when cut at the time the corn is nearly or fully ripe, the difference in digestibility cannot be very great.

So far as the qualiity of the silage made from corn cut at the different periods is concerned, all who have had experience agree that the early cut makes sour silage, and more of it spoils, while the corn cut nearly ripe, after the kernels are hard, makes sweet silage, and it keeps better in the silo, and is more palatable to cattle.

There can be no question but that silage from matured corn is a more desirable feed stuff in every respect than the watery, immature stuff made from corn cut when in the tasseling stage.

So much has been said in regard to early cut corn and other hays, as well as to early cut fodder corn, that the opinion prevails that all early cut forage is superior to the same matured. If a large variety of field corn is allowed to ripen and then cut and shocked and afterwards fed out whole, not more than one-half will be eaten, and hardly that by well fed cattle. Such forage would be much improved, no doubt, by cutting before the stalks become dry and woody, but mature corn stalks dried in the shock, and silage from the same, packed in the silo when fresh cut, are very different materials.

The first is not much more palatable to the animal than so much dry brush, while the latter is eaten with relish.

We have no complete data at hand as to the changes that take place in the feeding value of sorghum from the time it blossoms until the seed is ripe. The quantity of sugar increases up to full maturity, and the same is no doubt true of all the food elements.

We have found that sorghum ensilaged when the seeds were getting hard, keeps better and makes sweeter silage than when cut earlier, but if it is allowed to get over ripe, or is put in the silo when very dry, it becomes dry and musty.

We prefer to cut cow peas, either for hay or to ensilage, about the time the first pods begin to ripen, and we wonld put in red clover at the same time it is cut for hay.

For cutting down corn and sorghum in the fields, mowers 
and reapers have been used, but with heavy crops, cutting by hand with a corn knife is generally practiced. We prefer the knife shown in Figure 6 to the straight handle and blade.

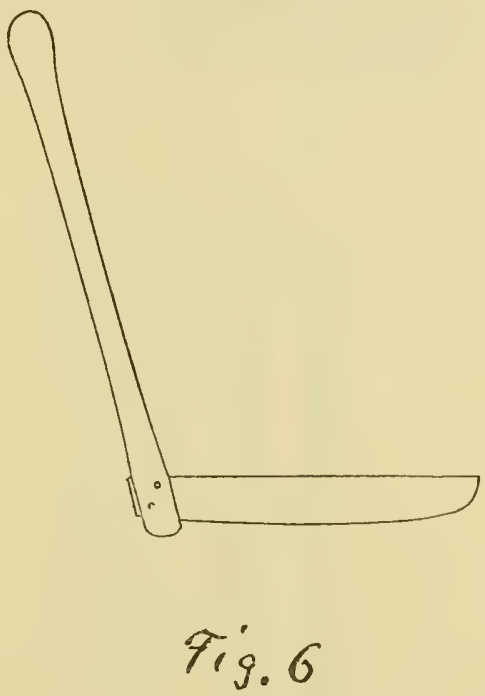

We cut and throw three rows together on the ground, in bundles as large as a man can pick up, stalks straight, butts even and all one way.

The bundles are not bound. A wagon with a wide frame is driven close to the bundles and the corn picked up and laid straight, crosswise of the wagon, butts all in one direction.

An ordinary farm wagon with hay rack will require a man on the wagon to luad, and the lifting from the ground to the wagon is heavy and slow work. A truck wagon with low wheels is a great improvement on the ordinary farm wagon, but the arrangement shown in Figure 7 is the best thing we know of for hauling the crop from the field.

The running gear of any farm wagon may be used. The pieces supporting the bed may be round poles, or sawed stuff $4 \times 6$ and $\mathrm{I} 7$ feet long. They may be attached to the rear axle with chains, or an iron rod passing over the axle and through the poles, with taps below. 


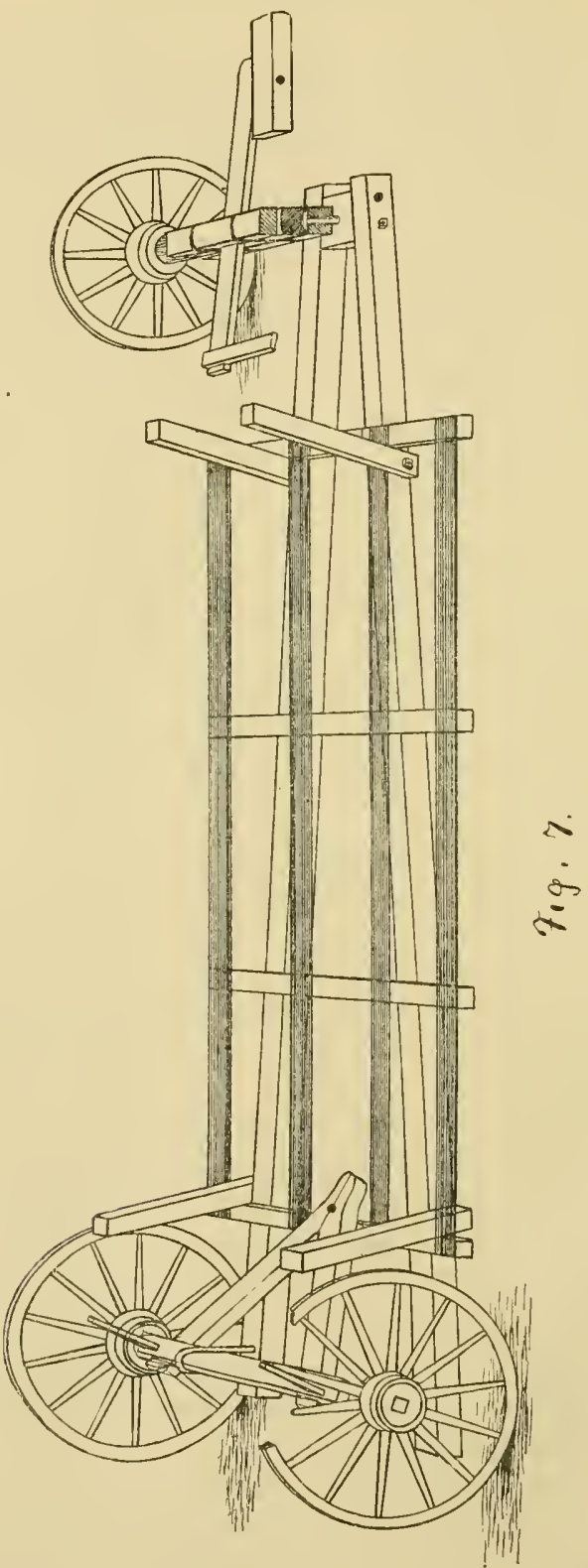

A false bolster, a, (Fig. 8) is attached to the front axle with chains, heavy wire, rope, or clevis made for the purpose. A king 
bolt, shown in the cut, passes through the false bolster and the block bolted between the head pieces of the frame. The king bolt should be $\mathrm{I} / \mathrm{T}$ inches in diameter, and fit loosely in the hole through bolster and block, or it will be liable to break, as it has to support a heavy load and horizontal strain. The frame should be six or seven feet wide ; cross pieces, $2 \mathrm{x}_{4}$ stuff; planks on top, ix6; standards to keep the load from the wheels, are $2 \times 4$, and may

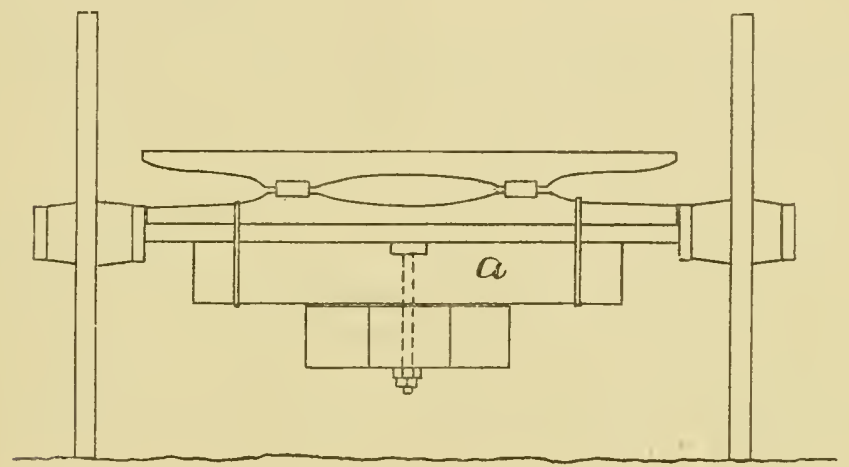

$$
\text { Fig. } 8 \text {. }
$$

be attached with $1 / 2$-inch carriage bolts and turned down flat out of the way when no load is on the bed. The front end of hounds on rear axle is attached to the cross piece on the frame. The pole, or wagon tongue, must be fastened to hounds on front axle in such way as to make it stiff, to keep the axle from turning. The lower side of bed pieces should be six or eight inches above the ground, so that the frame will not drag when the wheels run into a depression.

The load being carried so low, a man may stand on the ground and easily lay on as much green corn, or sorghum, as the team can haul, doing away with the necessity of a man on the wagon to load

This rack will be found convenient for hauling hay from the field when a horse fork is used for unloading, and save a good deal of the heaviest work in the hay field.

When the wagon is loaded it should be driven close to the rear end of the cutter table, butts of the stalks toward the cutter, so that the forage may be drawn straight from the wagon and run through the machine without lifting and turning it around. 
To carry out this arrangement the belt from the cutter should run forward to the pulley on horse power or jack, which should stand between the cutter and the silo. If there is not room between the cutter and the silo for the horse power, or engine, with the carrier straight ahead, an angle carrier may be used and the cutter stand parallel with the front side of the silo.

It is essential to have the cutter stand so that the loaded wagon may be driven up to the rear end of the cutter table, and the stalks moved straight forward on the table. The cutter should rest on the ground, or on a platform level with the ground, so that there will not be much lifting of the forage to get it on to the table.

We have dwelt on the loading of the wagon, and unloading on the table of the cutter, because this is the heavy and costly labor of the ensilage system. The handling of a crop weighing from ten to twenty or more tons to the acre is no small matter, and unless special care is taken to have everything arranged in the most convenient manner the cost of filling the silo will be greatly increased.

In handling a large crop we prefer to use three wagons and two teams. This allows one wagon in the field loading, one going from field to cutter while the other is being unloaded on the cutter. The men at the cutter move the wagon out of the way as soon as the load is off. The load from the field is left behind the machine and team taken off and hitched to the empty wagon to go after the next load.

The hands required to keep everything moving are, one man to feed the cutter, one to pass the forage to him from the wagon, a man to help load in the field, and a man with each team - the drivers to help load the wagons - two men to cut down the corn in the field, one man to level the chopped forage in the silo and tramp the edges and corners, and one man to look atter the engine or horse power. With the field near the silo, and sufficient power to run the cutter up to its capacity, this force of nine men should put in forty tons a day in ten hours, provided everything is managed so there will be no delays.

\section{THE CUTTER.}

There are quite a number of good feed cutters manufactured. We have used the cycle cutters, with the knives attached to the balance wheel, of which the Belle City is the type, and the revolv- 
ing knife head cutters, like the Ross, Silver Deming and others. We will not say that these machines are all equally good and durable, but we do not hesitate to affirm, after having used some five different makes, that more depends on having all the taps tight on the cutter, and a careful feeder who will be on the lookout for sticks, monkey-wrenches and other things that seem to have a propensity for getting into the forage, than on the particular make of the machine.

The knives must be carefully watched, for if they get loose something will be apt to break. The journals should be kept well oiled and knives sharpened as often as they become dull. The cutters all have carrier attachment, and the carrier is an essential part, unless the silo is in a basement and the cutter can stand above it.

The carrier should be long enough to extend up over the silo wall and one-third of the distance across the silo, so that the cut forage will drop in the center of the pit. If the silo is filled rapidly the cut forage should be well tramped down next to the walls and in the corners. If but two or three feet in depth of forage is put in each day it is well to let it pile up in the center of the pit and let it lie until the next morning in a loose heap, when it will be well warmed up, and then pitch the hot forage over against the walls, tramping it down as it is thrown over.

There need be no hurry about filling if the crop is not ripening rapidly, and stopping two or three days wlile filling will do no harm. If a break down occurs and the work has to stop for more than three days, level off the forage and cover with six inches of hay or straw. This coveting should be thrown out when filling commences again.

We have stopped nine days with the silo half full, waiting for a later planted crop to ripen, without any apparent injury to the silage. Fill to the top of the silo walls, and after the cut forage has settled for a day or two fill up again, and repeat the process until settling has ceased before putting on the covering. In a silo twenty feet deep the silage will settle five or six feet if filled rapidly, and refilling three or four times inside of two weeks will be necessary to have the silo remain nearly full after settling ceases.

We have stated that a layer of two feet of cut straw or old hay is as good a cover as anything, and that this layer of stuff will become moldy and unfit for food. If no cover is put on, the 
cut forage will simply spoil down for a foot or more, and this will act as a cover for the silage below.

\section{LENGTH OF CUT.}

We have found no advantage in cutting the forage very short. The finely cut may pack more closely. together, but cutting one and a half inches in length seems to answer as well as cutting finer. We left two of the knives off from our four-knife cutter last summer, and we find the silage is relished by the cattle, and keeps as well as when cut finer, and the capacity of the cutter is much increased.

Not more than three-fourths of the capacity claimed in the catalogues for the different sizes of cutters need be expected with average management, and at least one-third more power should be provided than they state is necessary.

\section{CHAPTER VI.}

\section{THE SILO.}

(x) ${ }_{3}^{3} \mathrm{E}$ present the plan of a silo which differs in construction from A the wooden silos built in some portions of the country, in having several horizontal girts in place of vertical studding, as in house building.

Our first wooden silo was built in this way. The horizontal frame work was suggested from the construction of the bins in grain elevators, where the resistance against side pressure has received a good deal of attention.

Our first silo lad brick walls, thirteen inches thick, laid in Portland cement, and it was nine feet deep, one-half in the ground. The second year we built a wooden frame work on top of the brick wall, making the silo eighteen feet deep. The silo was filled witl chopped corn sixteen feet, and in a few days the brick wall cracked near the ground, and if we had not discovered it at once, the entire wall on one side would have fallen out. We secured the wall with strong props, but the cracks spread sufficiently to cause considerable loss of silage next to the wall. Two years later a silo twenty feet deep, fifteen feet square inside, with ten-inch square posts at each corner, and 6xio horizontal girts, filled with wet and rather green corn, gave way at one of the cor- 
11ers, and the 6 xio girts sprung five inches in the centre. The silo was saved only by heavy props.

In 888 Prof. Shelton, of the Kansas Agricultural College, made some experiments with the dynamometer to determine the pressure against the walls of a silo, and found, twenty feet from the surface, with corn fodder cut in one-half inch lengths, the pressure was fifty-seven pounds to the square foot of wall.

Reasoning from this determination, Dr, Miles, referring to silos with vertical studding, says: "From the data thus furnished it will be safe to tuse $2 \times 4$ inch studs for a wall i 2 feet high, $2 \times 6$ inch studs for a wall I 4 feet high, and $2 \times 8$ studs for a wall I 6 feet high, if they are in each case placed ftom : 6 to I 8 inches apart from center to center, and sheathed on the inside by two thicknesses of inch boards, The sizes given are in fact considerably in excess of what is actually required to secure stability, if reasonable eare is exercised in other details of construction." "*

In our own opinion, the pressure against the walls is not altogethor a question of depth of the silo, or fineness of cut, and therefore cannot be estimated as in a grain bin, or tank for liquids, therefore we do not place much reliance on a single test to determine this point.

With three connected silos, we have noticed that there is no regularity in the pressure shown by the bulging out of the walls. We have made no tests to learn what causes the unusual pressure at times, or to determine its extent, but our observation has led us to believe that quite green or wet corn may produce a much heavier pressure against the walls than mature or partially cured corn, but not in proportion to difference in weight, and that forage rapidly filled in exerts more pressure than when filled slowly. There seems to be no regularity, as with two silos filled together on aiternate days, and with the same material, we have had one or two years, one to bulge out while the walls of the other would not spring perceptibly.

We are inclined to believe the pressure is largely due to the formation of gasses seeking an outlet, and not to the weight of the mass, but, as already intimated, this is a mere supposition, for which we have no experimental proof.

With the horizontal girts, the greatest strength and simplicity of construction is secured with the least material in the frame work, unless the silo is made round, and the girts are made in the *Silos, Ensilage and Silage, by M. Miles, p. 7 . 
form of hoops of several one-inch planks, one over the other, lapped and solidly nailed together. This method of building is suggested by one of our Texas correspondents, but we have not seen it tried.

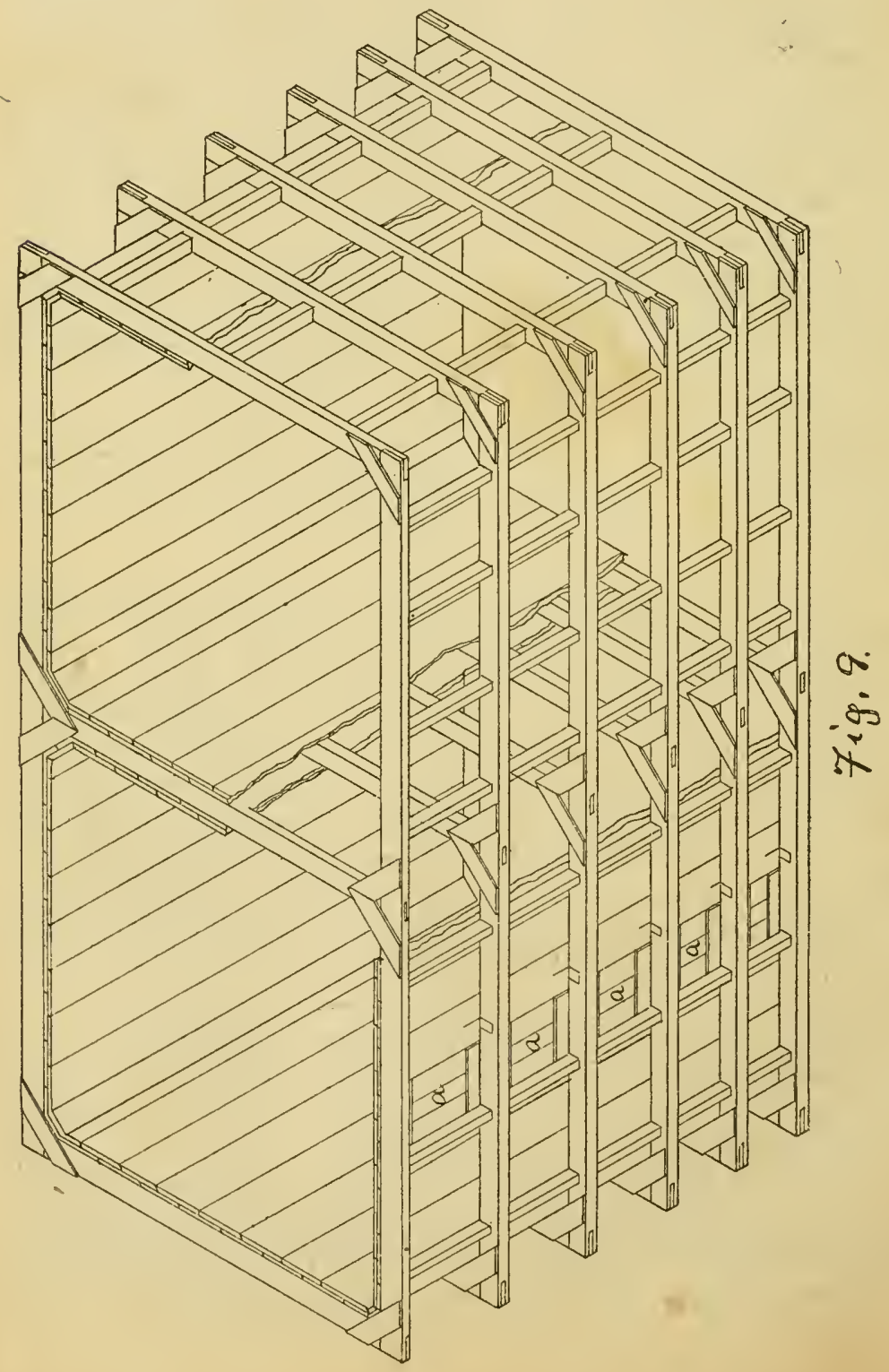


Figure 9 shows the frame work and lining of a double silo, each pit i 8 feet square inside and 20 feet deep. The ontside girts are made of $2 \times 10 \times 20$ feet planks, three planks in each girt, except the top girt, or plate, which has but two. The girts in the cross wall are made of $2 \times 8$ planks,

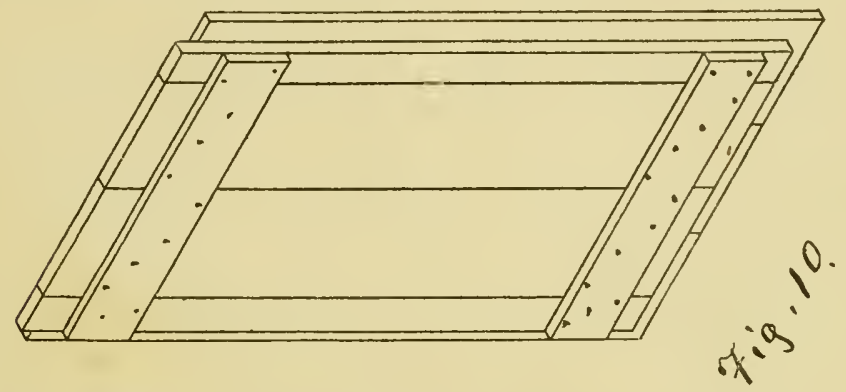

The corner framing is shown in Figure II, with the cross braces of $2 \times 6$ stuff $(a a)$. These braces are put in to dispense with the right-angle inside corners, but at the same time they

\section{$7,9,12$}

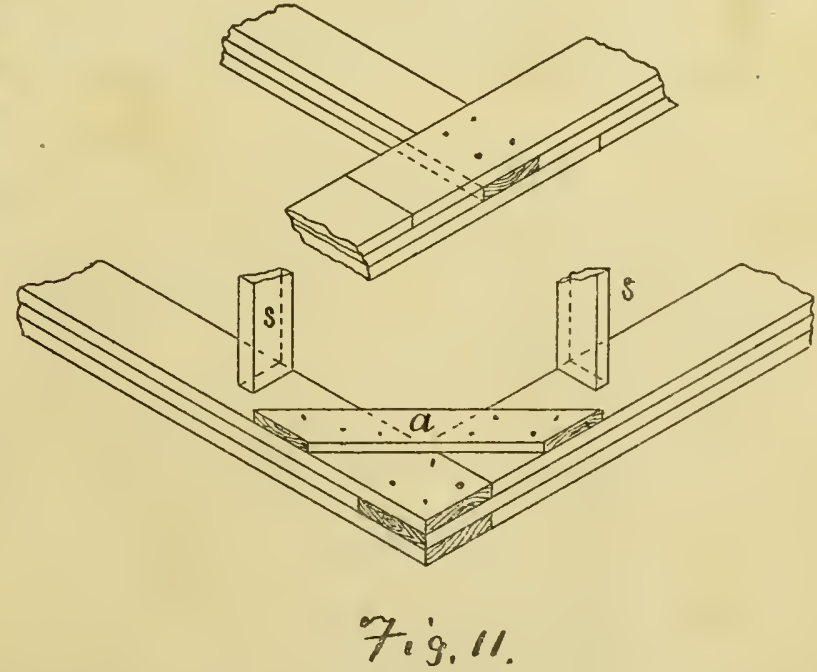

strengthen the corner joints and the intersection of the cross walls with the ontside (Fig. 12).

The doors are shown, $a$ a, Eig. 9, and detail of door Fig. Io. $s s$, Fig. I I, are $2 \times 6$ pieces sawed square at the ends and put in as the frame work is built up, to support the girts. 
It will be noticed there is no mortise and tenon work. The planks are simply sawed off square and spiked together with $20 b$ and $40 b$ nails. Two half-inch bolts should be put through the planks at the corner of each girt and at the intersection of cross wall.

Figure 12 shows how the ends of the planks of the outside girts lap over the cross wall girt center plank, on either side, above and below. The laps should be well spiked from above and below, after the frame is up, so that they cannot draw apart.

The silos are lined double inside with IX I2X2o feet planks extending from bottom of silo to top of plate. The planks are laid to break joints, as shown in Figure 9. It is well to have the lining planks dressed on one side, so that they will be of even thickness and lay smooth, but this is not essential. The inner planks should be of good, sound lumber, all heart if it can be procured.

Between the lining planks a layer of tarred building paper is placed to make the wall air tight. Dressed and matched flooring or ceiling is no better than good, common $1 \times 12$ planks for the lining. The lining will swell up tight when the moist forage is put into the silo. The lining planks should be well nailed to each girt, eight-penny nails in the onter plank and ten-penny nails in the inner.

BILI OF MATERIAL.

FEET T.

105 pieces $2 \times 10 \times 20 \mathrm{ft}$. sills, girts and plates.... . 3,500

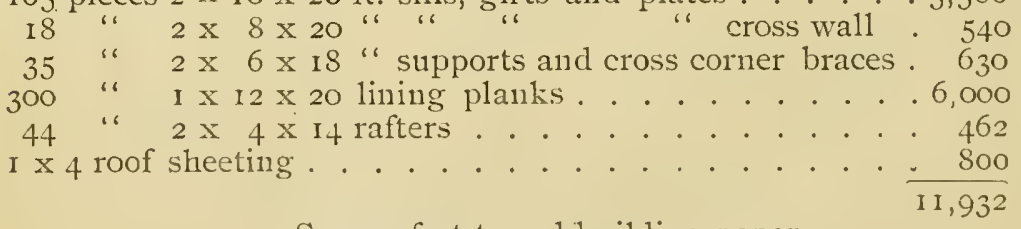

3, ooo Square feet tarred building paper.

Io M Shingles.

75 1/2"x 7 " Iron bolts.

$1501 / 2$ " Washers

I Keg 4o-penny nails.

2 Kegs 20 penny nails.

2 Kegs Io-penny 11ails.

I Keg 8-penny nails.

30 pounds 4 -penny nails.

Brick foundation wall i 2 inches thick, is inches high:

4,500 Bricks.

2 Barrels lime.

2 Barrels cement. 


\section{CONSTRUCTION}

Build the silo on dry ground, on a sliglit elevation, so that water will not stand near the walls. Dryness may be secured by cutting a ditch a foot deep around the silo, if the ground is flat. A I2-inch brick or stone wall six inches high above ground, and foundation below frost line, for the sills to rest on, will make the best job, but when the means are limited lay the sills on blocks, four inches above the ground, and after the silo is built lay a IXI 2 plank on edge inside against the lining, and fill the floor with dirt up to the bottom of the sills. When the silo is emptied pull the dirt back from the walls, so that the air will pass under, filling in again before putting in the next crop. With a brick or stone foundation, fill with dirt nearly to the top of the wall. If the sills rest on a wall the sills should be anchored to the wall at the center, with a $3 / 4$-inch bolt bedded in the wall and passing up through the sill at the side of each silo, to hold the sill from springing out on the wall and ietting in air. A short piece of $2 \times 4$ stuff bedded lengthwise in the wall, flush with the top, to which the lower plank of the sills may be spiked, will answer the same purpose.

Having the material on the ground, commence with the planks for the plates. Saw them the proper length and lay on the ground at one side of where the silo is to stand, in the same position they will occupy in the silo. Continue with the planks for the girt next below the sill, and so on till all the planks are fitted and the girts piled one above the other, the sills on top. The inside edges should be plumb and even.

By this method, laying each plank in place as soon as fitted, no mistake need be made, even by one who has but little mechanical skill. After all the pieces are cut and in place, take off the upper run of planks, cross wall and all, which will be the lower run of the sill, lay it on the foundation and see that it is level. Follow with the second plank, spike together at intervals of two feet with 2o-penny nails, and then the third plank, and spike with 40-penny nails, and the sill is complete. Cut up the $2 \times 6$ supports (s, Fig. II), 23 pieces 2 feet 6 inches long, set up in place and toe nail with lo-penny nails.

Lay on first run of planks of first girt, and spike on top of $2 \times 6$ supports. See that it lies plumb with the sill, and stay with 
temporary strips on the outside. Proceed as directed until the frame is all up, taking pains to see that each girt is plumb with those below, and braced or stayed sufficiently to hold it rigidly in place.

The second run of $2 \times 6$ supports ( $s$, Fig. II) are 3 feet long, third run 3 feet 6 inches, fourth run 3 feet 9 inches, fifth and last run 4 feet 5 inches. The supports either side of the doors should stand plumb one above the other, but a slight variation will not matter with the others.

After the frame is up, put on first layer of lining planks and follow with the tarred paper. We prefer to cut the rolls of paper into lengths of 20 teet and 6 inches, and tack up the strips vertically. Let the edges lap about two inches and use just enough 6-ounce tacks to support the paper, and follow with the inside lining plank, breaking joints with the outer plank.

A few planks will have to be ripped to fit in the corners and not have one crack come over another.

If the planks are seasoned and dry, it will add to the durability of the lining to paint the inside with hot coal tar.

If coal tar is used it should be boiled down until it will get nearly hard when cold. If the planks are green leave off the paint until the next summer.

The tar may be put on with a swab made of a rag tied on the end of a stick. Tarred paper should be put between the planks on the doors, and it is well to tack strips of paper over the cracks around the doors when filling the silo.

The silo is slown without a roof in order to display the inner construction. A good roof is one of the essentials, and it may be of whatever style is most convenient, but if quite flat, it should rest on a second plate three feet above the silo wall proper, to allow room for tramping the silage next to the wall.

The floor of the silo may be covered with brick, cemented or grouted, but a dirt floor answers very well if it is higher than the ground outside, so that it will keep dry. If the ground is sandy it will be well to cover the floor with three or four inches of clay, moistened and packed down solid.

The roof the silo should project two feet all around, to throw the water away from the building and to keep the foundation dry.

In the Gulf States the building need not be weather-boarded, so far as the silage is concerned, but from the central to the northern part of the country the outside should be sheeted and bat- 
tened, and in the extreme north, building felt should be tacked on to the girts under the sheeting to protect the silage from frost.

\section{A Cheap Silo.}

For the benefit of those who desire a cheap silo, we submit a plan which provides for posts set in the ground (Fig. I6). The

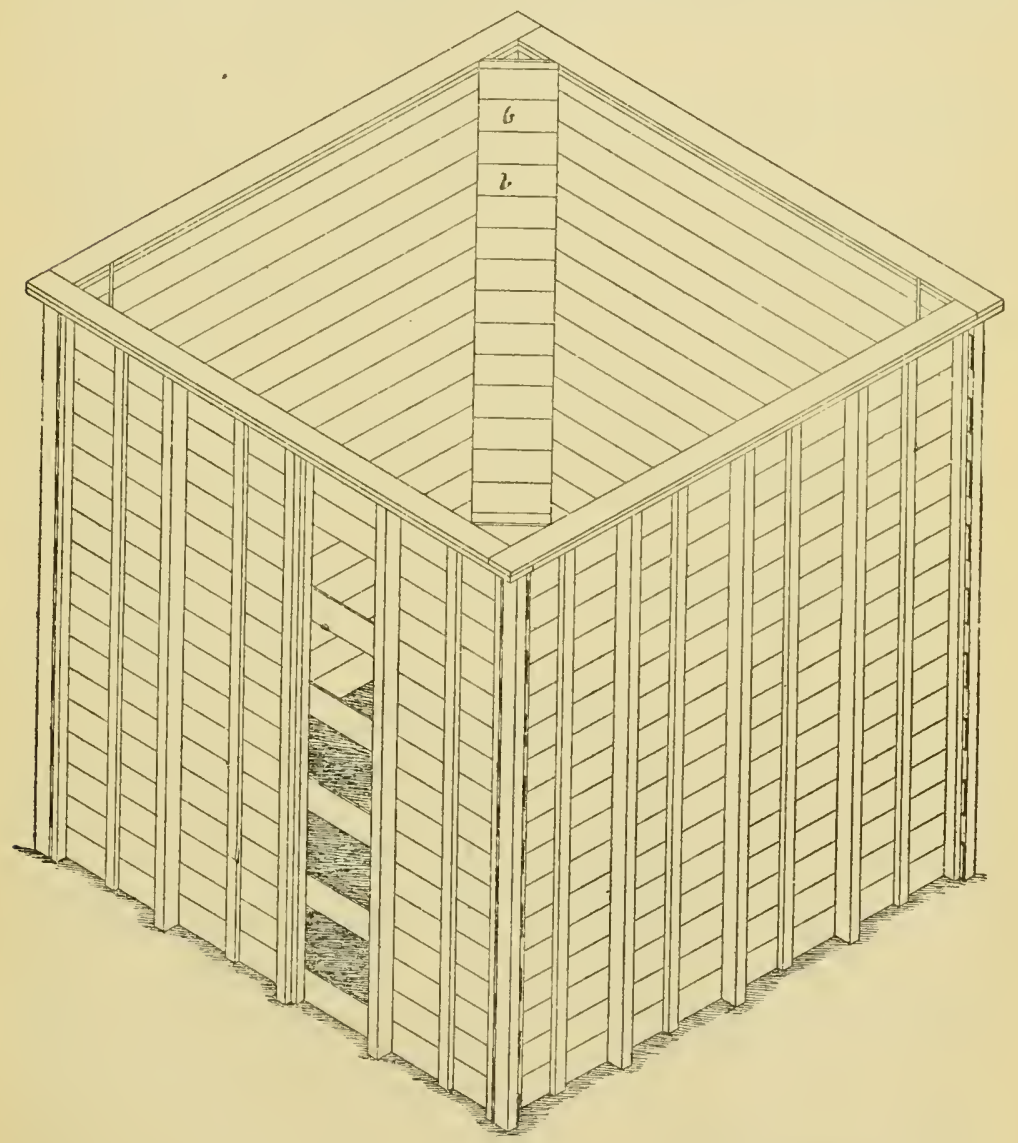

\section{7 is.16}

plan shows a silo $16 \times 16$ feet inside and i 8 feet deep. The posts are round poles hewed straight on one side. [The posts are shown squared in the drawing.] The bill of material includes lumber and shingles. 


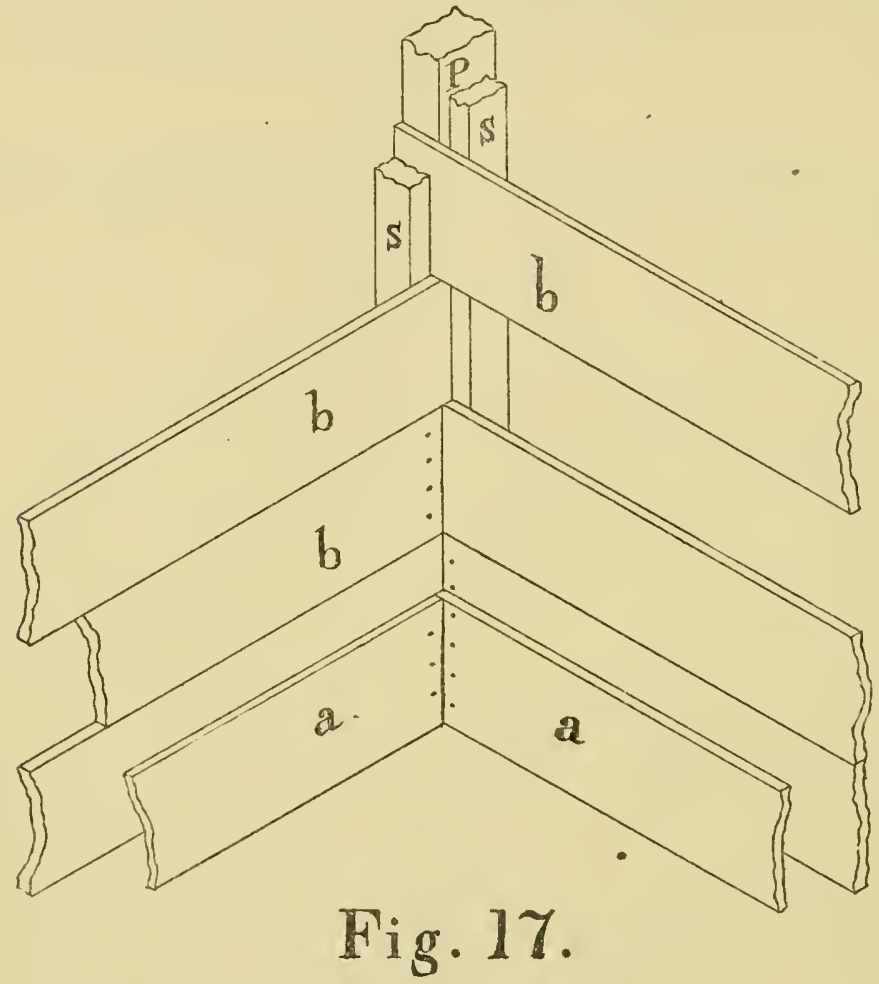

BILI, OF MATERIAL.

FEE'T.

56 Planks, I X $12 \times 18$ outside lining and corners . . . I, oo8 I 2 " 2 I X I2 X I6 Inside lining . . . . . . . . . I,792

24 " $2 \times 4 \times$ I8 outside corners and between posts . 288

8 " $2 \times 10 \times 18$ plates ......... . 240

20 " $2 \times 4 \times 12$ rafters . . . . . . . 160

Strips roof sheeting . . . . . . . . . . 250

Shingles, 5 squares . . . . . . . . . . . 4,000

I6 Posts 2 I feet long, 6 inches in diameter at upper end, surfaced one side, corner and door posts surfaced two sides.

I 5 pounds 40-pen11y Nails.

20 pounds 20-penny Nails.

50 pounds Io-penny Nails.

50 pounds 8-penny Nails.

I2 pounds 4-penny Nails. 


\section{SPECIFICATIONS.}

Silo 6 feet square inside, I 8 feet from ground to lower side of plates.

Raise the ground floor of the silo six inches higher than the surrounding ground by filling in, or a ditch may be dug around the silo after it is built.

If round posts are used for posts, surface and line two adjacent sides of six posts for the corners and each side of the door, and one side of the remaining ten posts.

Lay off on the ground and dig lioles for the posts, making them some larger than the butt ends, so that the posts may be lined on the inner surfaced sides. Set up all the posts so that the faces on each side of the silo are in line, and form a square $16^{\prime} 2^{\prime \prime}$ inside of silo; plumb and stay lath, taking pains to see that the posts on each side are in line bottom and top.

Set posts on sides of door to leave space between, of three feet, and see that the sides that form the door jambs are plumb and parallel.

Saw off upper ends of posts level, put on lower plank of plate and spike well to each post; lay on upper plank, spike corners firmly and over each post.

Put on lower outside lining plank, ends extend out on corner posts on two sides to make corners solid, as sliown in detail of corner in Figure 17 , and put up $2 \mathrm{x}_{4}$ pieces between posts. These pieces are put in to keep plank from warping when silo is empty.

Spike two four-inch pieces on surfaced side of posts on sides of door, inner edge flush with inner surfaced side of posts.

Sheet up with outside lining plank, cutting out 2 d-3, 5-6, S.9, II-I2, I4-I5, I7-IS planks from bottom, even with center of edge of $2 \mathrm{x}_{4}$ " forming door jambs. See that the pieces are cut exactly the same length, and that the openings left are same width, and that the pieces will just fit in loosely.

Cover plank with tarred paper, edges lapping two inches, put on inner lining plank, ripping plank for bottom, so that the outer and inner linings will break joints. Inwer lining plank butt together in corners.

Cut off all the inner lining plank over holes left for doors two inches longer on each side, so as to make a lap joint when the pieces are put in. These pieces strould all be of the same length, so they will fit any part of the opening. 
Saw up IxI2" plank, pieces 20" long, ends beveled to fit, and nail in the corners as shown at $b$, Figure r6; cover with paper, extend out on wall two inches, then cut more plank to fit outside of first, breaking joints as with the siding.

Fill in floor with earth at least three inches upon plank lininglbefore filling with forage, and when silo is emptied rake dirt back from plank until ready to fill again.

\section{Capacity of the Silo.}

The first plan given shows a double silo, to illustrate the method of building two or more silos attached together.

A single silo may be constructed on the plan shown, or a silo may be fitted up in a barn or other building.

The size of the silo may vary to suit the requirements of the farm or herd, but we would rather have two medium sized silos than one quite large one. If large-twenty feet or more in length or width-a heavy frame will be required, as no ties can be put crosswise inside to support the walls. A rod or beam through the mass of silage will make an open air space as the forage settles, and cause the silage around it to rot. With the horizontal frame work shown in the first plan, the silo may be any depth desired without requiring heavier material to sustain the pressure, and as a deep silo will have greater capacity in proportion to inside measure than a shallow silo, owing to the greater compression of the contents, we would prefer to have the silo deep rather than have it long or wide.

In feeding out the silage we prefer to take off the entire covering and remove a layer of the silage from the entire surface each day. With a very large silo this would not be practicable, unless a large leerd of cattle is fed.

The weight of a cubic foot of silage in the silo will vary with the depth of the mass and with the condition of the forage when put in. If the crop is harvested when nearly matured, or if the forage is allowed to wilt in the field after cutting, before it is ensilaged, it will not be so heavy as it would put in green and succulent.

In silos twenty feet deep our silage, put up as recommended, weighs from 35 to 40 pounds to the cubic foot, and a cubic foot makes a little more than a day's ration, with grain, for a cow or Iooo-pound steer. 
In the Northern States a cubic foot of silage is generally estimated at 50 pounds, and this also represents nearly the amount required to feed a cow in milk, or full grown steer, for one day.

In building a silo, therefore, the capacity in cubic feet, after deducting two feet from the upper surface for settling, will fairly represent the number of days' feed the silo will hold. This supposes the silo to be filled until settling ceases at the time the crop is harvested.

From the estimates given, one of the silos slown in the first plan will lold 5,832 days' feed for one cow or steer, or i 6 days' feed for 50 steers.

\title{
CHAPTER VII.
}

\author{
Silage as a Feed-Stuff.
}

is

NSIDERABLE attention has been given to the question of stock feeding, both in Europe and in this country, and many experiments lave been made to determine the food values of many of our farm and mill products.

The individual variation in any class of animals, even under similar conditions, renders it impossible to formulate exact rules for feeding, and when we have to consider feeding different kinds of animals, and feeding for different purposes, the question becomes still more complicated.

A sufficient number of experiments, however, have been made to give us some light on the subject, and to enable us to lay down a few general rules which, although not exact, perhaps, for any one animal, are near enough correct to guide us in the preparation of food rations for our stock. Without going into a detailed account of the principles of feeding, we will simply state that the food ration should contain some definite amount of certain materials, and these materials should be in certain proportions to give the best results in feeding. 
The digestibility and chemical composition of the materials used will largely determine in what proportions they should be combined. By digestibility is meant that part of the food which, when taken into the stomach of an animal, will be absorbed into the system, and not simply passed through and excreted as solid dung.

The digestibility of different feed-stuffs varies as a whole, and in certain elements found in nearly every material used for food.

In the analysis of any food the chemist finds a certain proportion of what he calls albuminoids, fats and sugar, starch, and crude fibre, and the first such part of the food as contains nitrogen.

The experiments in cattle feeding indicate that the best results are obtained when the digestible albuminoid part of the food bears some definite relation to the digestible carbo-hydrates, including the fats, and from this the quantity of each kind of food to be mixed together to form the daily ration is estimated in making up food tables.

As stated, owing to the variation in animals, and to the different purposes for which they are fed, and to the fact that the amount the animal will digest is not always the same, the exact proportion of the two cannot be given, but a sufficiently close estimate may be made to be of great assistance.

It has been found that the ration should contain one part of digestible albuminoids to from four to six parts of digestible carbohydrates, including fats estimated as carbo-hydrates.*

If we examine the composition of some of our common feed stuffs and estimate the digestibility as determined in actual feeding tests, we find, as a rule, the proportion is wider, or narrower, than the one given, and that to secure the proper proportions, we will bave to prepare a compound containing two or more materials.

We present a table slowing the composition of the digestible part of several foods.

*The digestible fats in a food are estimated to be worth two and a ha!f times as much as the carbo-hydrates, and in the following table the amount of fats in the food given is multiplied by two and ore-half and the sum added to the carbo-hydrates in making the calculation. 
One Hundred Pounds of the following materials contain on an average of digestible elements:

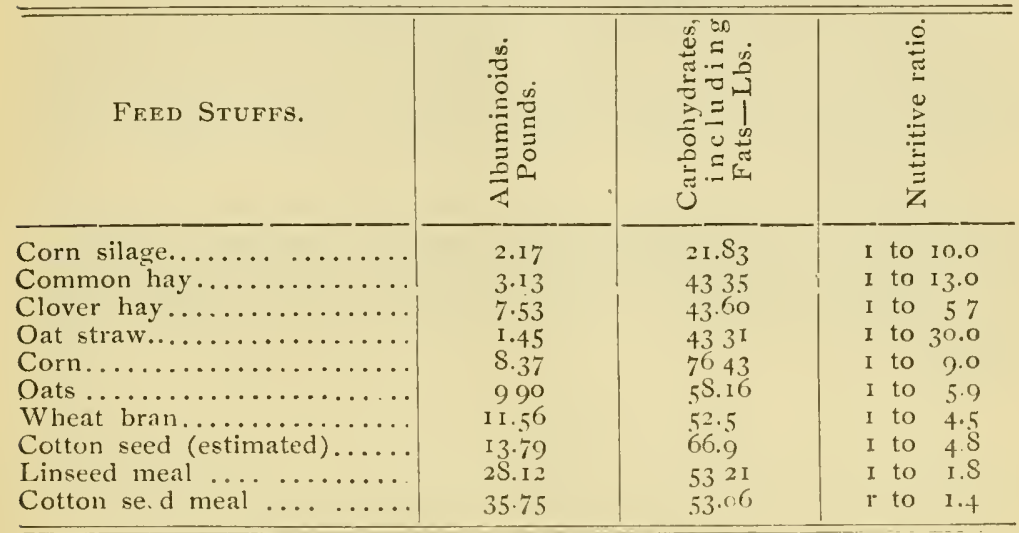

The German feeding experiments indicate that a fattening ox weighing 1000 pounds should have a daily ration of $2 \frac{1}{2}$ to 3 pounds of digestible albuminoids and 12 to 16 pounds of digestible carbohydrates.

The table shows that a steer would have to eat more than 100 pounds of silage daily to get the requisite amount of albumoids, and in doing this he would eat more than is required of carbo-hydrates. We notice the same difficulty with common hay, and the oat straw is still farther out of the way.

Clover hay contains about the right proportion of the two in. gredients, but the steer would have to eat $33^{\mathrm{T} / 3}$, pounds per day to get 2.52 albuminoids and 14.5 pounds of carbo-hydrates, a greater quantity than he can dispose of.

Eating 20 pounds of corn per day of which the ratio is I to 9 , the animal would get the proper amonnt of the latter ingredient but not enough of the former.

Twenty-five pounds of oats per day, with a ratio of I to 5.9 would supply 2.42 pounds of albuminoids and 14.54 pounds of carbohydrates, about the right proportion. The same amount of wheat bran would also make a properly compounded ration, and the same is true of cotton seed.

Cotton seed meal has a very narrow ratio, 1 to $1.4 ; 25$ pounds would be required to supply I2.I pound. of carbohydrates but this would give nearly 9 pounds of albuminoids, three times as much as is needed. Linseed meal has also a narrow ratio. 
From the table we see that corn is not the proper grain to feed with oat straw, silage or hay, as they all have too wide ratios; oats are better and cotton seed and wheat bran still better, but cotton seed meal and linseed meal give us the best proportioned foods to mix with silage and other foods having a wide nutritive ratio.

To illustrate the manner of using the table we present several combinations of feed-stuffs prepared from analyses made by the experiment station chemists, and as the rations given have been tested in feeding, we are confident they will prove satisfactory.

Compounding Food Rations.

\begin{tabular}{|c|c|c|c|}
\hline VARIETY. & $\begin{array}{l}\text { Albuminoids. } \\
\text { Pounds. }\end{array}$ & $\begin{array}{l}\text { Carbolyydrates } \\
\text { and fats. } \\
\text { Pounds. }\end{array}$ & $\begin{array}{l}\text { Nutritive } \\
\text { ratio. }\end{array}$ \\
\hline $\begin{array}{l}\text { No. I- } \\
25 \text { pounds corn silage } . . \ldots \ldots \\
\text { I } 5 \text { " cotton seed......... }\end{array}$ & $\begin{array}{r}.54 \\
2.07\end{array}$ & $\begin{array}{r}545 \\
\text { I } 0.00\end{array}$ & \\
\hline 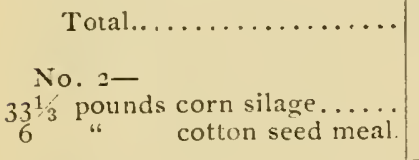 & $\begin{array}{l}261 \\
.72 \\
2.14\end{array}$ & $\begin{array}{l}15 \cdot+5 \\
7 \cdot 27 \\
3 \cdot 18\end{array}$ & I to 5.9 \\
\hline 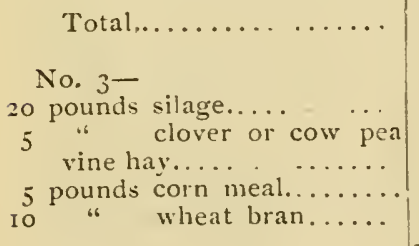 & $\begin{array}{r}.43 \\
.37 \\
.+1 \\
1.15\end{array}$ & $\begin{array}{l}4.3^{6} \\
2.1 S \\
3 S_{2} \\
525\end{array}$ & I to $3 \cdot 6$ \\
\hline 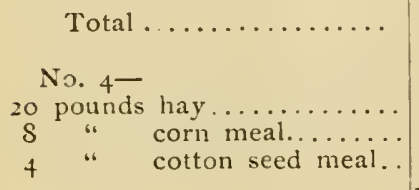 & $\begin{array}{r}.62 \\
.67 \\
1.43\end{array}$ & $\begin{array}{l}\text { S.66 } \\
6.11 \\
2.12\end{array}$ & I to 6.6 \\
\hline Total............... & 272 & $16 S_{9}$ & I to 6.2 \\
\hline
\end{tabular}

The preceding rations are given to show how different feedstuffs may be combined to make the proper ratio of albuminoids and carbo-hydrates. 
In compounding such rations the cost of the different accessible feed-stuffs will determine to a great extent what should be used, and it must be remembered that the taste of the animal will also have to be consulted, as he may refuse to eat a sufficient quantity of certain foods that would otherwise be economical to use.

It is not claimed that a ration having a nutritive ratio within the limits given will always give better results than a wider or narrower ratio, but it will be found on trial that as a general rule, something approaching the above formulas will give the best results.

\section{CHAPTER VIII.}

Cattige Feeding.

HE limits of this book will permit of only a few suggestions in regard to cattle feeding, and what we have to offer will refer more particularly to feeding in the Southern States.

We repeat here what we have said under "Suggestions to Feeders," in Bulletin No. 6, of the Texas Agricultual Experimental Station:

"Two things are essential in fattening animals:

"I. To keep the animal comfortable and quiet.

" 2. To induce him to eat the largest possible amount of nutritious food.

"One is of little value without the other. To keep the cattle comfortable, shelter from rain is indispensable. Cattle fall off as rapidly during a cold rainy spell in Texas, with the temperature at the freezing point, or a little under, as they do in Dakota, with the temperature below zero.

"Range cattle, as a rule, will not do their best under close confinement, $i$. e., tying up by the head. They may be shut up in a building, but need room to move around.

"Wild cattle must be handled quietly. This point we wish to cmphasize, for it is entirely overlooked by too many cattle men. A barking dog and a noisy, loud-mouthed man are two things that should never be permitted to enter a cattle feeding pen. It should be remembered that when a naturally wild steer is struck with a whip or disturbed in any way, he stops gaining weight for a time, and food consumed is a loss. 
"This is not a sentiment, but a business matter of working the animal machine to its full capacity. Dehorning seems to affect a wild steer somewhat as 'throwing' the horse in the Rarey method of breaking colts. Then the head remaining sensitive for some time, wild steers are subdued and stand quietly together in a way that must be seen to be believed.

"We are of the opinion that steers should be dehorned but a short time before shutting up to feed, so that they may be fattened while their heads are somewhat tender.

"FEeding.

"Cattle should be fed twice a day at a regular time, if confined in a building, by the same persons, and strangers excluded for at least a month after cattle are shut up. Feed what the cattle will eat and clean out mangers and troughs once every day. Cattle dislike food that has been picked over and breathed on.

"Vary the rations occasionally to stiminlate the appetite; have salt always before them, or better, if the feeder is careful and skillful, sprinkle a little salt on the food, but care must be exercised not to give too much."

Steers that have been grown on farms where they are accustomed to seeing people, and cows that have been milked, take to close confinement better than the range cattle and thrive better when tied up in a barn, but having had considerable experience in feeding both classes of cattle, in both northern and southern states, we have but one plan to recommend, and that is to remove the horns by sawing them off close to the head and feed the cattle running loose, under shelter, without tying.

If handled quietly and supplied with the right kind of food, and with not more than one hundred head together in one pen, and the cattle of nearly the same size, we believe this method of feeding, taking into consideration the labor of getting the food to the cattle, disposing of the manure, and gain in weight, will give the best results.

Dehorning is a simple and safe operation, much more so than castration. With a properly constructed chute for holding the animal or by throwing him on the ground the horns may be cut off with a light butcher's saw, an ordinary carpenter's back saw, or with one of the saws made specially for the purpose.

Experiments in Wisconsin, Tennessee and Texas, and the thousands of animals operated on in the northern states, show 
that the removal of the horns does not seriously effect the animal if the work is properly performed, nor does it cause shrinkage in weight.

\section{THE BeST FoOD TO USE.}

Where corn can be grown or procured for 20 cents per bushel or less and good hay is worth not more than three dollars per ton, if the climate is mild and not too wet, it is doubtful if feeding on corn and hay in racks in open dry lots sheltered from the wind, with hogs running with the steers can be improved upon.* Such a system of feeding is wasteful, but economical feeding means getting the largest return with the least outlay, and any system in which the extra cost of labor exceeds the value of food saved by the system, is neither economical nor scientific.

Our suggestions are made for the benefit of those who are situated where corn and hay are worth more than the values given above.

Corn is king as a stock grain food for the country at large aud it is perhaps the cheapest food to use in several of the central and west central states.

In the greater portion of the cotton belt, cotton seed and cotton seed meal supplies a cheaper fattening food than corn, and particularly so when fed with corn, and sorghum silage, or other food lacking in nitrogenous matter.

Competition in beef production has lowered the value of beef cattle to the extent that only by the most economical system of feeding and the use of food stuffs that supply nutriment in the cheapest form is there hope of making the business profitable.

In fact the indications are that profitable cattle feeding will in time be largely confined to sections of the country, or particular localities where cheap food can be supplied and the cattle will be moved from the breeding and grazing ground to those places.

A large area of the southern states is adapted to the production of cheap cattle food. Corn and sorghum for silage may be grown at less cost and with more certainty than in the northern states, and for hay, the cow pea, Johnson grass, Bermuda, Japan clover, red clover and other plants are not surpassed in yield and quality by the hay plants elsewhere.

* The corn and hay ration may be improved by adding a little boiled cotton seed. The cattle will fatten faster, and the cost per pound gain be less it seed are not worth above ten cents per bushel. 
For the grain or richer part of the ration corn is produced in portious of these states, and particularly in Texas, as cheap as in Kansas or Illinois, but cotton seed and cotton seed meal will probably continue to be the cheapest concentrated cattle food to supplement or replace corn for very many cattle feeders.

Cotton seed hulls also supply a valuable coarse food for cattle feeding, being equal in value to good hay pound for pound.

A feed ration of hulls and cotton seed meal alone gives as good results in fattening as corn and hay.

In our feeding experiments last winter* six native Texas steers, three and four years old, averaging $74 \mathrm{I}$ pounds live weight at the beginning, made an average gain of 202 pounds each in $S_{3}$ days, or a gain of 2.43 pounds per day. 6.74 pounds of cotton seed hulls and 2.79 pounds of cotton seed meal were consumed for each pound gain in weight.

Estimating the cotton crop at $7,000,000$ bales annually, the cotton seed crop amounts to some 3,500,000 tons, which would yield sume $1,750,000$ tons of cotton seed hulls and I, 31 2,000 tons of cotton seed meal, if the oil were extracted from the entire crop of cotton seed, or three-fourths of the quantity after deducting. one-fourth of the crop for planting and waste.

The arerage market price of cotton seed on the plantation is not more than $\$ 6$ per ton, and the average price of the meal and hulls at the cotton seed oil mills is about $\$$ I 8 and $\$ 2$ respectively. The use of cotton seed for cattle feeding, with corn and other forage crops that the southern climate is specially adapted to produce, supplies food for fattening cattle and feeding dairy cows at the minimum cost.

\section{PREPARATION OF THE FOOD.}

So far as digestibilty is concerned, chopping, grinding and cooking food adds nothing in cattle feeding, except in the case of hard grain and seeds that the animal will not masticate well. Such seeds may pass through the stomach and be excreted without giving up their nutriment.

The manipulation of the food in the ways referred to, particularly in chopping coarse fodder and mixing ground grain with it, may make the food more palatalsle, and by this method the animal may be induced to eat more food and to eat certain things he would reject if fed whole and alone. 
For example: In feeding whole, matured dry corn fodder, 25 to 50 per cent of the stalks will be rejected; with corn in the shuck, the cob and shuck will be left, whereas, if the first is chopped fine and meal sprinkled orer it, it will nearly all be consumed, and if the corn, cob and and shuck be ground up together the animal takes it without question.

Cattle will pull out and waste a good deal of hay or other forage when fed whole, which they will not do with chopped feed, so that chopping, grinding and cooking may be of value in saving food.

The manipulation of the food adds to its cost, and if one is not careful the labor expended will amount to more than the value of the food saved.

The more costly the food, the more we can afford to expend in labor to have it consumed without waste, and to add to it cheap materials that will not be eaten when fed alone. So far as cooking food is concerned, it may be profitable in hog feeding, but the stomach of the ox is so well designed for preparing the food for assimilation that not much if anything is gained, except to make the food more palatable in some instances.

We have always found it more profitable to cook cotton seed for cattle, and simply because the cattle would eat more seed when cooked; but with cooked corn, or other grain, the cattle relish the foud no better, nor do they make any more rapid gain, as has been shown by repeated experiments. Cotton seed may be either steamed or boiled, but we would not recommend steaming unless a steam boiler is required for other purposes.

For steaming the seed, a vat or box, of metal or of wood, with a lid that can be fastened down quite tight, is necessary, and a good head of steam must be kept on for three or four hours to soften the seed. Water must be put in with the seed, as they will not cook unless fully saturated. We have cooked cotton seed in both ways, but boiling has given so much greater satisfaction that we continue to use the boiler in preference to steaming, although we have a steam engine and boiler at our command.

For a few cattle, one of the cauldron or stove boilers, holding from 50 to 75 gallons and costing from $\$ 15$ to $\$ 20$, is convenient, but for a large herd a boiler may be made that is less expensive and more economical in the use of fuel. 
Bili, of Lumber.-Fefeding Shed 27xio8 Feet.

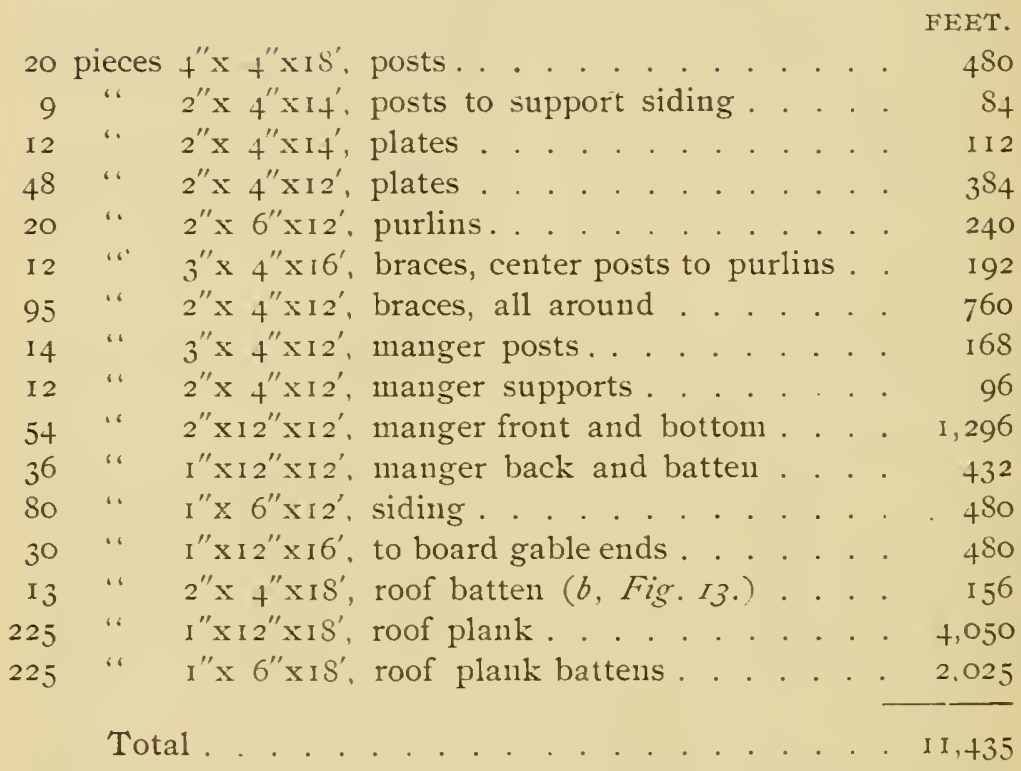

FLOOR.

FFET.

400 pieces $2 " \times 66^{\prime \prime} \times 12$, flooring. . . . . . . . . 4,800

24 " $2 "{ }^{\prime \prime} t_{4} " \mathrm{XI} S^{\prime}$, to support floor plank . . . . . 288

9 “ $2 " x 6 " x 1212$, center supports of floor.... 108

Total. .

Specifications of Feeding Shed.

Twenty-seven by ios feet, for feeding from 80 to ilo head of dehorned steers.

Figure I 3 shows cross section of building, posts, ends of purlin plates $(p p)$, battens $(b b), 2^{\prime \prime} \times 4^{\prime \prime}$ stuff to stiffen roof plank and keep them from warping, ends of mangers $(m m)$, braces to support purlins $(a a)$, ends of siding. 
Cattle Feeding.

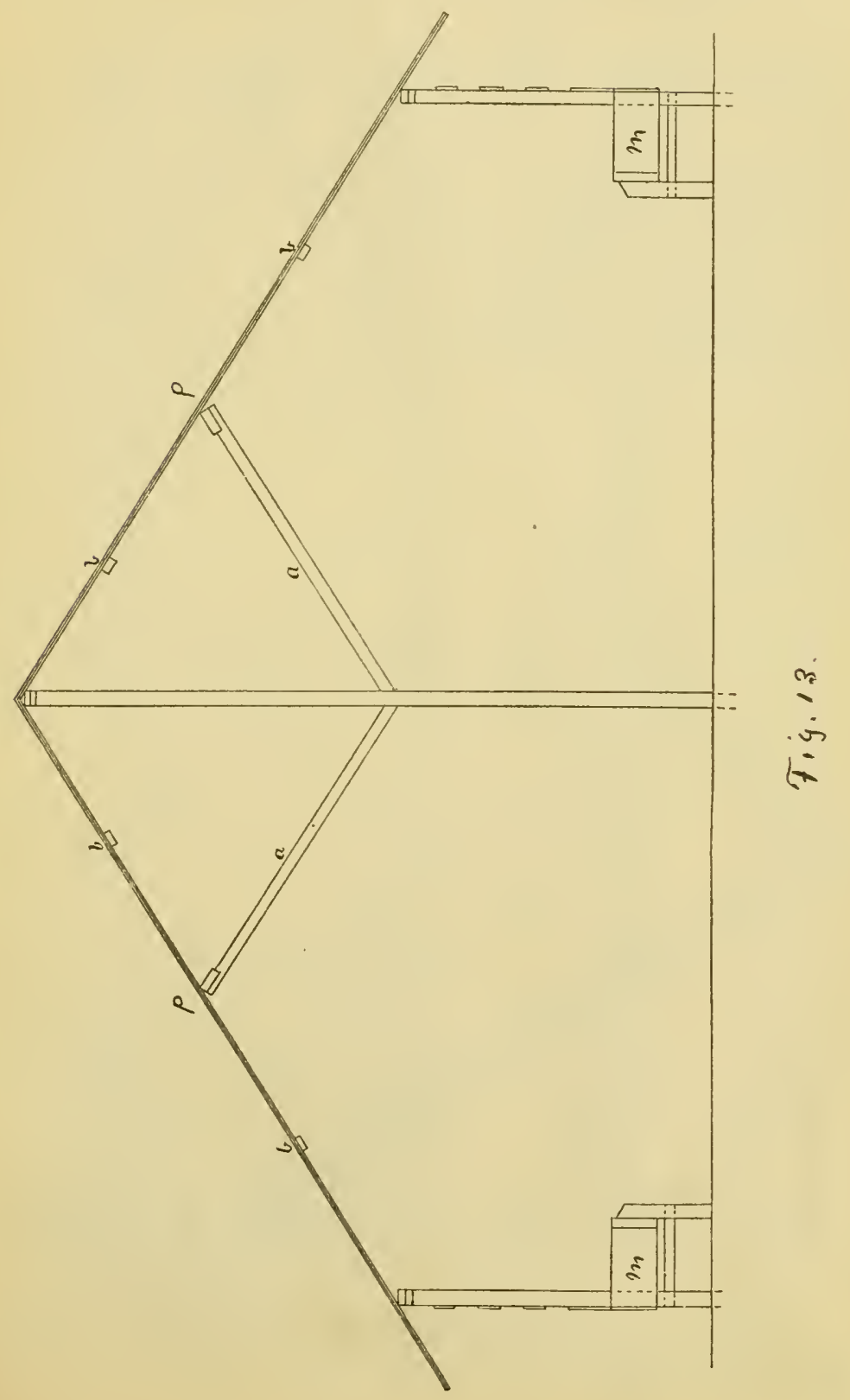




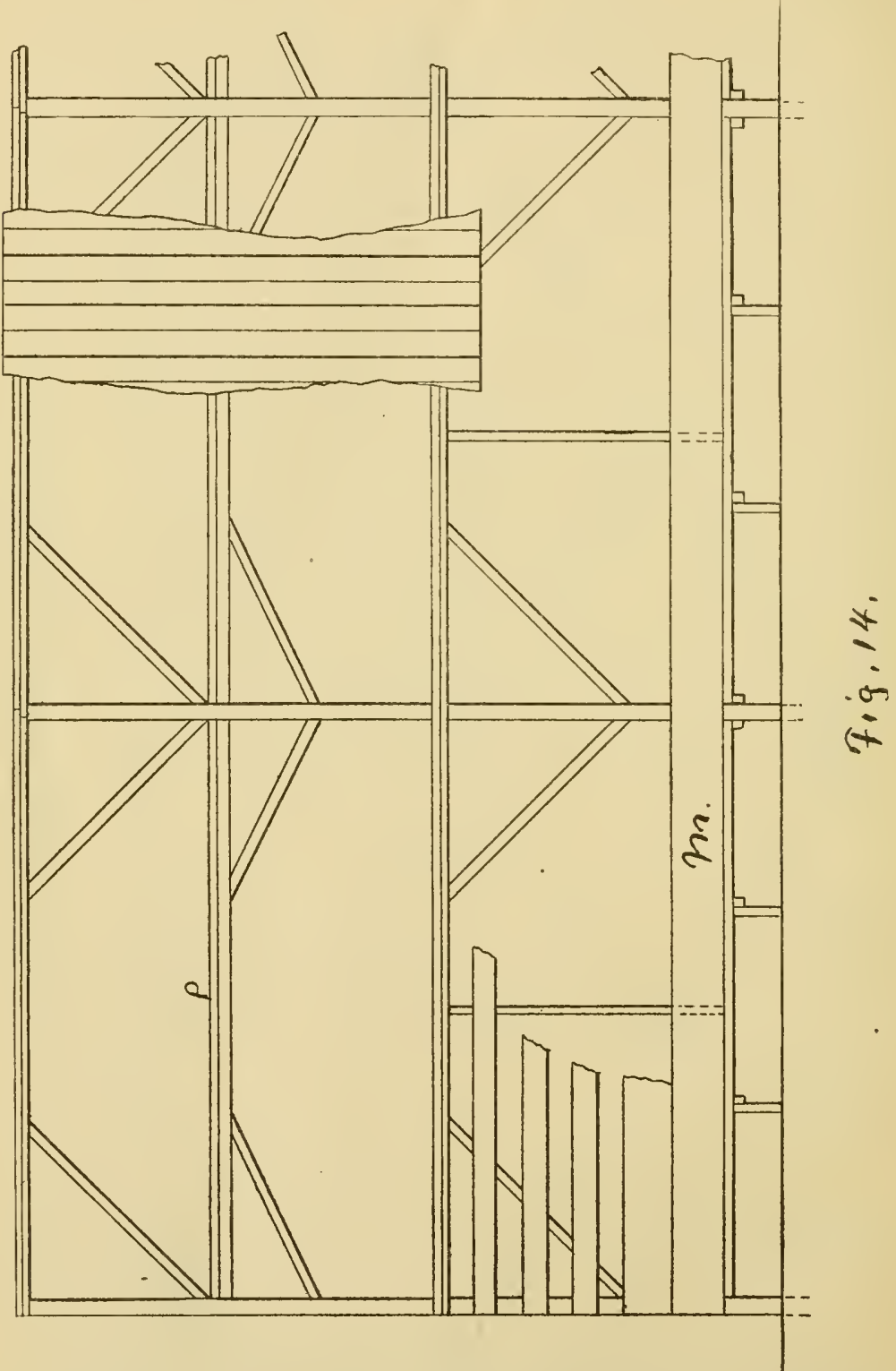

Figure I4-View from side, showing posts, and braces from posts to plates, purlin plates $(p p)$, back of manger $(m)$; also section of roof plank. 
Cattle Feeding.

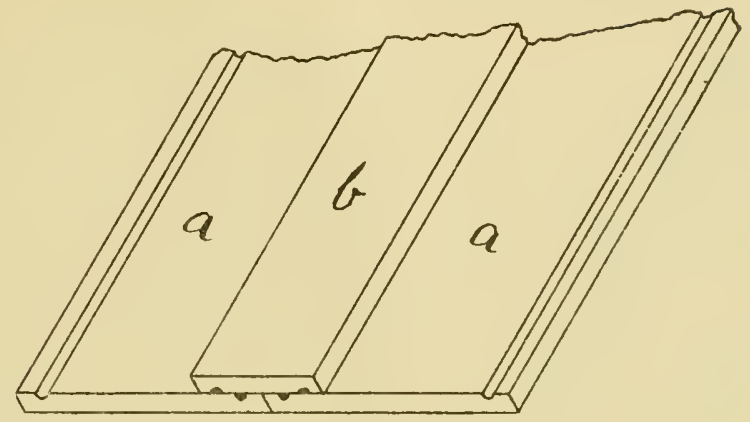

Fig. 15 .

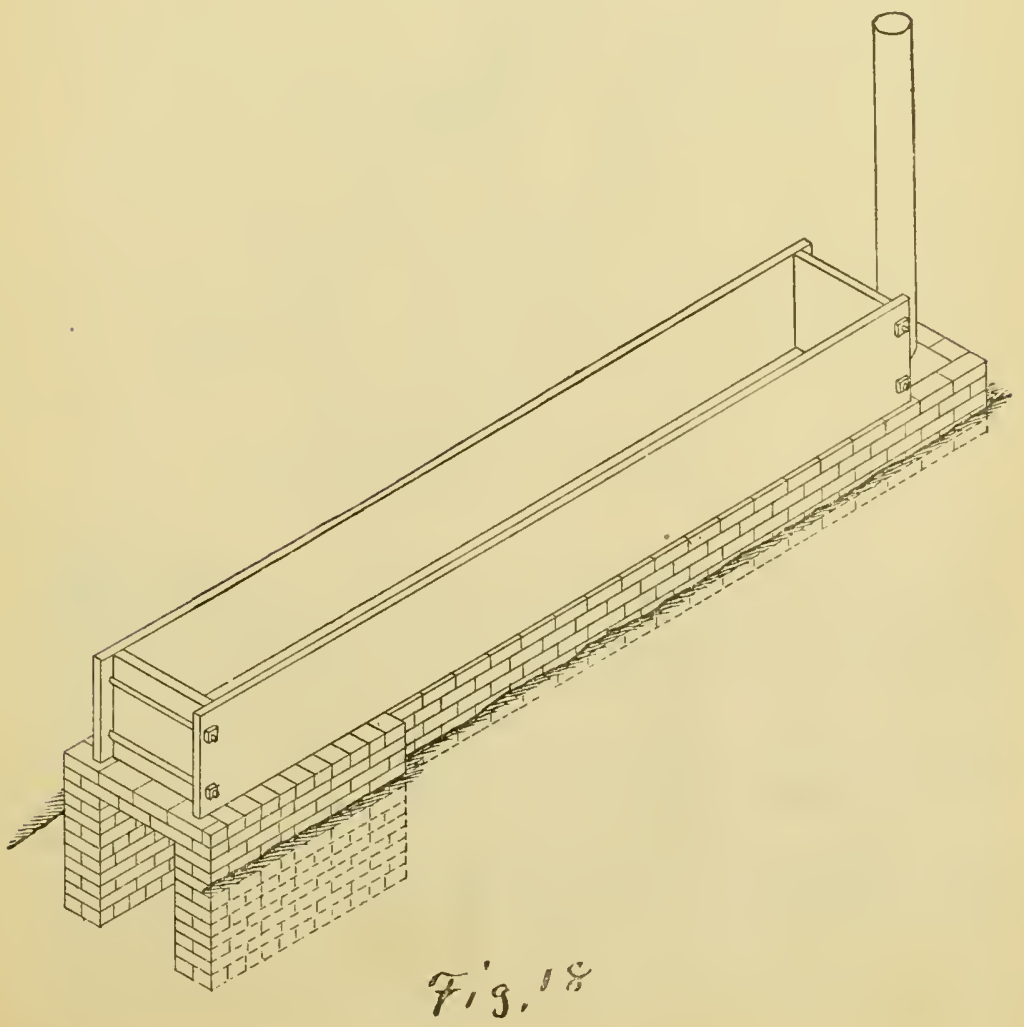




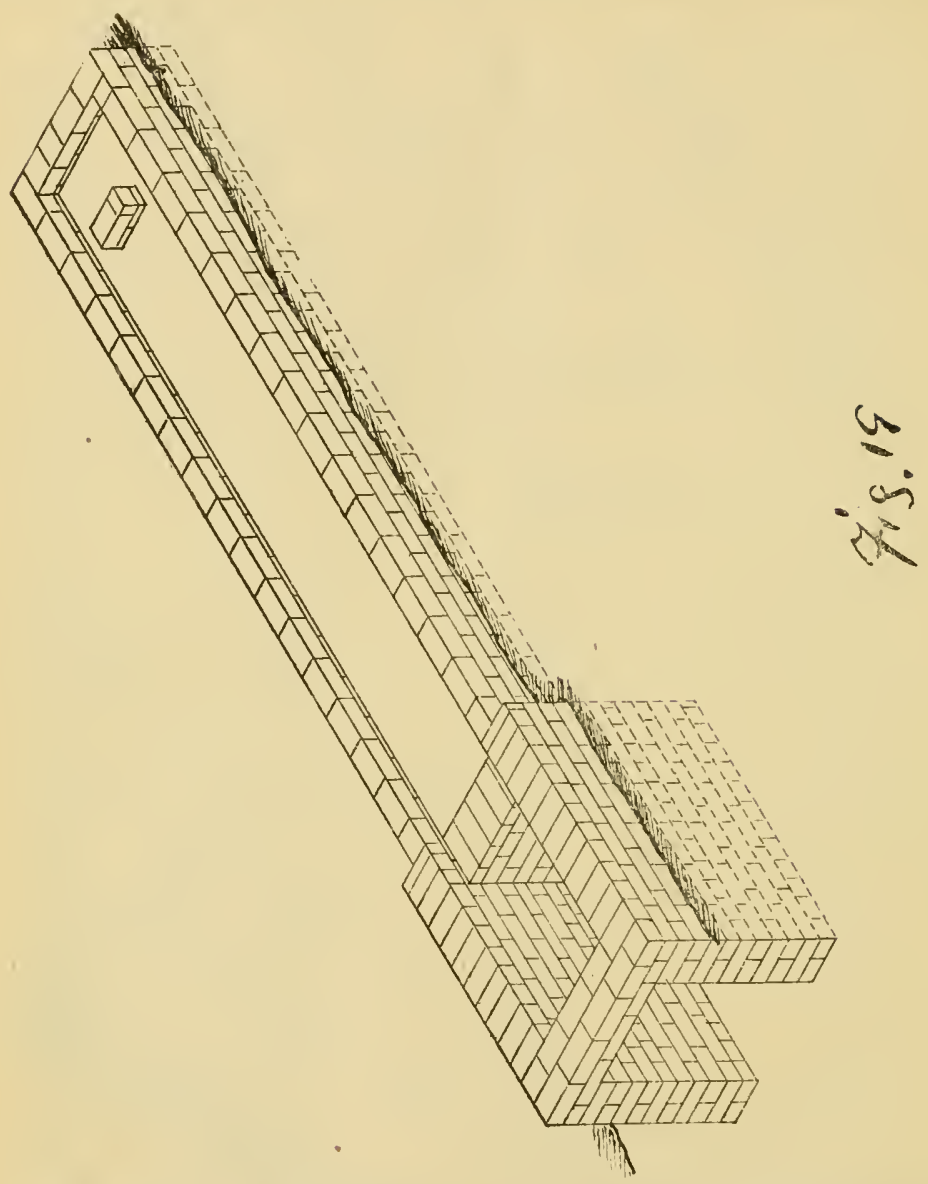

We present a plan of a boiler (Fig. I8) we have used for several years with good resuits. It is simply a wooden box two feet wide, two feet deep, and fifteen feet long, with galvanized sheet-iron bottom nailed on, set on a brick wall. When fuel is somewhat expensive it is well to put in grate bars under the fire, and make the fire-box not more than three feet long, and sixteen to twenty inches from grate to bottom of the boiler. When wood is no object make the fire-box five feet long, and allow two to two and a half feet from bottom of fire-box to boiler, and use wood four feet long. The wall around the fire-box should be eight inches thick, but a twelve inch wall will last 
longer, and it should have a foundation carried down six inches below the bottom of the fire-box.

The back wall of the fire-box (Fig. I9) should be four inches lower than the side walls, and the space back of this filled level with dirt to carry the heat close to the bottom of the boiler.

The short inside cross wall near the rear of the boiler foundation (Fig. I9) is put in to support the pipe, or stack, and to check the heat from passing out too rapidly.

Back of the fire-box a four-inch wall is all that is required.

Figure is shows boiler and brick-work complete, and Figure I 9 the brick-work. The irregular line along the side of the wal represents the surface of the ground.

Bill of MAterial For CotTon SeEd BoIler.

2 plank $2^{\prime \prime} \times 24^{\prime \prime} \times 16$ feet.

2 plank $2^{\prime \prime} \times 24^{\prime \prime} \times 2$ feet.

4 iron bolts $1 / 2$ " $\times 29^{\prime \prime}$.

I piece galvanized sheet-iron (No. I 7 guage), $28^{\prime \prime} \times 155^{\prime} \times 4^{\prime \prime}$.

4 pounds I I/4" wire nails.

750 brick.

2 bushels of lime.

\section{CHAPTER IX.}

\section{Cattle Feeding Shed.}

66 Sold weight if exposed during the cold, wet weather, the opinion is common that shelter is impracticable. In fact it has been found that range steers will not always thrive when tied up and closely confined. Their legs stiffen and swell up; they will not always eat, and as turning out and tying up again each day is entirely out of the question there is reason for the common opinion. We assume that economical feeding must include shelter, and that the solution of the problen, how to make sheltering practicable, is essential to an improved and profitable method of feeding. "'*

*Texas Expt. Station Bulletin, page 5 . 
It has been held that shelter for cattle is unnecessary in the warm climate of the Sou'hern States, but it is probable that cattle shrink more when expose ${ }^{1}$ to the cold and protracted rain storms in the South than they do when exposed to the severe but dry cold weather in the Northern States.

Our own experience leads us to believe that shelter is one of the essentials in economical cattle feeding even in the Gulf States.

We submit plan of a cattle-feeding shed suitable for the Southern States, or for a colder climate if boxed in, designed to hold the largest number of cattle, with a minimum of space, and material required in the building.

In feeding in such a building the cattle must be dehorned or the weaker ones will not do well, and not so many cattle will stand quietly together and feed.

The shed is designed for the Southern States, and is therefore not boarded up on the sides, but even here it is well to board up the north side and end to protect from cold winds and driving rains.

\section{FEEDING SHED.}

The plan (Fig. I3) shorvs cross section of the building, and Figure I4 shows two bents from the side. The shed is twentyseven feet wide, and the roof is supported on three rows of $4 \times 4$ posts, set in the ground, and twelve feet apart from center to center.

Poles from the woods may be used for posts, but we have included the posts in the bill of lumber.

Figure 15 shows ends of roof planks, with grooves in upper surface of wide plank $(a)$, and on lower side of battens $(b b)$ to prevent water from working under; planks $(a a) I^{\prime \prime} \times 12^{\prime \prime} \times 18^{\prime}$, planks (b b) I" $\mathrm{I}^{\prime \prime} \mathrm{x} \mathrm{I} 8^{\prime}$.

\section{CONSTRUCTION.}

Center posts 4 " $\mathrm{x}_{4}$ "X 18 ', set 3 feet in the ground; 15 feet from ground to ridge pole; posts on sides 4 " $\mathrm{x} 4$ " $\mathrm{x} 9$ ', set 2 feet 4 inches in the ground.

Plate and ridge pole pieces butt together on posts, as shown in plan, and are spiked with 2o-penny nails; all extend 2 feet 
beyond posts at ends of shed; all braces cut with beveled ends to fit, and nailed with I2-penny nails.

Purlin plate $(p)$ is let in I inch on 3 " $x_{4}$ " supporting braces (a, Fig. I3), and piece of I"x6", 2 feet long, nailed on upper side of purlin joints to hold plates from drawing apart.

A, Figure 15 - I"Xi2" roof boards to have groove $3 / 8$ of an inch deep and I inch. from edge on each side on upper surface, and some with battens (b, Fig. 15) on under surface, as shown in Figure 15 .

Roof boards to be nailed to plates, purlins, 2 "x4" batten ( $b \quad b$ Fig. 13 ) and ridge plate, three 8 penny nails in each, and battens with ro-penny nails, two nails in each. Any split or badly checked roof plank should be rejected.

\section{MANGERS.}

Front and bottom of 2 "xi2" plank, back of I"X I2" plank, a $2^{\prime \prime} \times 4$ " piece to be placed at the center of each bent, extending from ground to plate (Fig. 14 shows this piece cut off at bottom of manger), aud let in and nailed to back side of manger battens, to which manger back and siding are nailed.

The 3 " $4_{4}$ " posts supporting the manger to be set 1 foot in the ground. Short posts at back side of manger, between posts of shed; cross-pieces of 2 " $\mathrm{x} 4$ " under manger, spiked to posts, to which bottom of manger is nailed, upper edge of front of manger 2 feet 3 inches above floor.

\section{FLOOR.}

If the shed stands on sandy land no floor will be required, and it may be dispensed with on any dry soil if a little dry bedding is used. When the ground is flat and wet it may be best to put in the floor.

The floor is made of $2^{\prime \prime} \times 6^{\prime \prime} \times 12^{\prime}$ stuff, laid crosswise of the shed, ends meeting at the center under the ridge pole. The opposite ends will just reach under the mangers.

Before laying the floor the ground is to be made smooth, with a moderate slope from center to side of shed, and two runs of 2 " $\times 4$ " $\times 18$ ' stuff laid flush with the ground, lengthwise of the shed each side of the center posts, one run just inside of the manger, the other half way from manger to center posts. One run of 
2 "x6"Xi2' stuff to be laid in the same way on the line of, and between the center posts. The flooring is laid on the pieces bedded in the ground, ends meeting on the 2 " $x 6$ " pieces at the center and spiked to all the pieces.

A $3 / 4$-inch space to be left between the floor plank to catch and hold litter and prevent the cattle from slipping. Flooring plank should rest on the ground; the strips underneath are used simply to hold plank in place.

Gates may be hung at the ends of the shed, to shut the cattle in or out. The gates should be wide enough to allow the passage of team and wagon to haul in feed and hanl out manure. The feed may be put in from the outside by leaving off one of the siding plank above the manger.

The manger is designed for silage and chopped feed, but it may also be used for hay. If hay is to be fed with silage it will be well to construct a rack over the manger, from which the hay may be pulled by the cattle.

With a small herd of cattle-less than fifty head-and especially in a dairy herd, it is desirable to have the silo and place for storing feed attached to the shed that shelters the cattle, to save labor in feeding, but in feeding a large number of steers not much is gained from having the storage and shelter buildings all combined, and the certainty of total loss if one catches on fire makes it a hazardous risk.

The buildings should not be far apart, and they should be so arranged that the feed may be easily loaded on to a wagon, or cart, and the load hauled close to the mangers and the feed shoveled or pitched in.

The cattle will fatten faster if confined to small lots near the feeding shed, and they should be shut inside the shed during bad spells of weather. Nothing will be gained by allowing the cattle to run over the pastures during winter, while feeding. The little grass they get will take away their relish for dry feed, and really do more harm than good. The fattening season should be made as short as possible, and to secure this the cattle should be induced to eat as much as they will. Changing from one lot to another, turning in a new lot of steers-anything that excites or 
disturbs the cattle, tends to check consumption of food, and with it gain in weight.

Much more might be written with reference to the selection and preparation of feed stuffs for cattle, and we would like to dwell on the importance of skill and care in the management of the work in feeding. Constant study of the requirements of the animal is necessary to secure the best results.

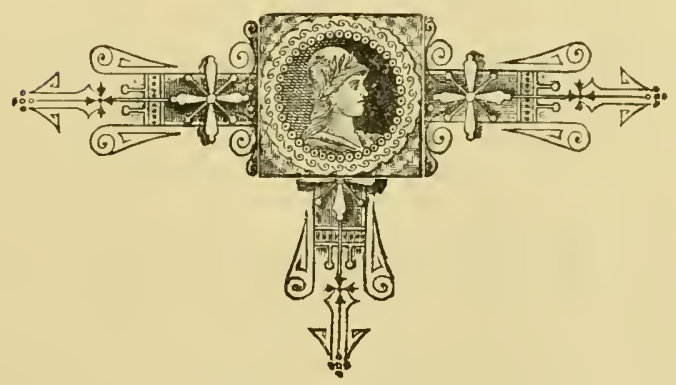





\section{INDEX.}

PAGE.

Albruminoids . . . . . . . . . . . 46

"nalysis of Silage . . . . . . . . . . 22, 24

Analysis of Silage Northern and Southern Varieties of Corn. 23, 24

Bedding Land for Corn . . . . . . . . . I I7

Bedding Land-Single and Double Beds . . . . . . . I7

Carbo Hydrates . . . . . . . . . . . . . . ${ }_{4} 6$

Cattle Dehorning. . . . . . . . . . . . 50

Cattle Feeding-Close Confinement . . . . . . . 62

Cattle Feeding, Study of . . . . . . . . . . . 45

Cattle Feeding, on Cotton Seed Hulls and Meal . . . . 52

Cattle Feeding-Suggestions to Stock Feeders . . . . . 49

Cattle, How to Feed . . . . . . . . . . . 50

Cattle, Quiet Handling . . . . . . . . . . . 49

Clod Crusher . . . . . . . . . . . . r 8

Cooking Food for Cattle . . . . . . . . . . . . $5^{2}$

Corn, Amount of Food from an Acre... . . . . . 20

Corn, Amount of Sugar in . . . . . . . . . . . . . 22

Corn, Best Variety for Silage and for Dry Forage. . . 2 I

Corn, B. \& W. . . . . . . . . . . . . 21

Corn, Certainty of Crop. . . . . . . . . . . 19, 20

Corn, Composition of Different Varieties . . . . . . . 22, 27

Corn, Cutting When in Tassel . . . . . . . . 26

Corn, Distance Between Stalks . . . . . . . . . . ${ }_{16}$

Corn, Double and Single Beds . . . . . . . . . I7

Corn, Dry Matter in . . . . . . . . . 22, 24, 27

Corn, Early Planting . . . . . . . . . . . 18

Corn, Effect on of Rich and Poor Soil . . . . . . . . . 15

Corn, Flat Culture and Bedding Land . . . . . . . . . $\quad 16$

Corn, for Dry Forage . . . . . . . . . . . . 21

Corn, Growing for Both Grain and Forage . . . . . . $\quad 15$

Corn, Habits of Growth in Different Latitudes . . . . . . 15, 22

Corn, How to Grow . . . . . . . . . . . . . . ${ }_{15}$

Corn, How to Plant............. . . 18 
Corn, Injury from Deep Cultivation ......... I 19

Corn, in Kansas . . . . . . . . . . . . . . ${ }_{15}$

Corn, Large vs. Small Varieties . . . . . . . . . . 23

Corn, Not a Complete Food . . . . . . . . . . . 48

Corn, Quality Affected by Method of Growing . . . . . . 16

Corn, Replanting . . . . . . . . . . . . . . 18

Corn, Root Development . . . . . . . . . . . . 19

Corn, Sweet Varieties for Silage . . . . . . . . . . 21

Corn, Thick Planting . . . . . . . . . . . 16

Corn, Varieties, Northern vs. Southern . . . . . 21, 22

Corn vs Cotton Seed as a Feed Stuff . . . . . . . 5 I

Corn vs. Sorghum Silage . . . . . . . . . . ${ }_{15}$

Cotton Seed, Boiler . . . . . . . . . 57,58

Cotton Seed, How to Cook . . . . . . . . . . 53, 58

Cotton Seed Hulls . . . . . . . . . . . . . . 52

Cotton Seed Meal . . . . . . . . . . . . I 2

Cotton Seed Meal, Composition of . . . . . . . . . . . 47

Cotton Seed Meal for Feeding . . . . . . . . . . . . 52

Cotton Seed, Raw vs. Cooked . . . . . . . . . . . 53

Cotton Seed vs. Corn as a Feed Stuff . . . . . . . . . $5^{1}$

Compounding Feed Rations . . . . . . . . . . . . ${ }_{48}$

Cow Peas, When to Harvest for Silage . . . . . . . 28

Crops Best to Grow for Silage . . . . . . . . . . . 14

Crops for Silage Put up Whole. . . . . . . . . . . 9

Covering for Silage in the Silo. . . . . . . . . . . 8

Cultivation, Deep and Shallow . . . . . . . . . . 19

Cultivation of Crops for Silage . . . . . . . . . . 15

Dry Forage, Difficulty in Curing . . . . . . . . I1, I 2

Dry Forage, Loss in Feeding . . . . . . . . . . . 11

Dry Forage vs. Silage . . . . . . . . . . 9, 10

Donra . . . . . . . . . . . . . . 25

Dehorning Cattle. . . . . . . . . . . 50

Definition of the words "Silo," "Silage" and "Ensilage." 6

Decomposition of Silage . . . . . . . . . . . . . . . . 6

Early vs. Late Harvesting Forage . . . . . . . . . . . 26

Ensilage Crops, Yield per Acre . . . . . . . . . . . 15

Ensilage, French System . . . . . . . . . . . . . 7

Experiments, Corn Growing in Wisconsin . . . . . . . 22

Experiments, Corn Growing in New York . . . . . . . 26

Experiments, Corn Growing in Pennsylvania . . . . . . 27

Experiments, German Feeding Cattle . . . . . . . . 47 
Experiments, in Dehorning Cattle . . . . . . 50

Feed Cutters, Best Kind . . . . . . . . . . . . . . 32

Feed Cutters, Carrier for ... . . . . . . . . 33

Feed Cutters, Capacity of ...... . . . . . . 34

Feed Cutters, Care in Running . . . . . . . . . . 33

Feed Cutters, Setting Up . . . . . . . . . . . 32

Feeding Barn, Material for ... . . . . . . . . 54

Feeding Barn, Plans and Specifications. . . . . . 55, 59

Feed Stuffs, Amount Coitsumed per Day . . . . . . . 47

Feed Stuffs, Composition of . . . . . . . . . 46, 47

Feed Stuffs, Cooking . . . . . . . . . . . I3, 53

Feed Stuffs, Digestibility of . . . . . . 13, I4, 46

Feed Stuffs, Palateableness of . . . . . . . . . 13

Feed Stuffs, Succulent Condition of ......... . 13

Feed Stuffs, the Best to Use . . . . . . . . . . . $5^{1}$

Floor for Cattle Feeding Shed . . . . . . . . . 6 I

Floor for Silo . . . . . . . . . . . . . . 40

Food, Chopping, Grinding and Cooking . . . . . . . . 53

Food, Cooking for Stock . . . . . . . . . . . . 13

Food, Preparation of . . . . . . . . . . $55^{2}$

Forage Crops, Yield of . . . . . . . . . 9, 22, 24

German Feeding Experiments . . . . . . . . . . 47

Goffart's Method of Filling the Silo . . . . . . . . . 7

Harvesting Silage Crop . . . . . . . . . . . 26

Harvesting Silage Crop, cost of . . . . . . . . 32

Harvesting Silage Crop, Labor Required . . . . . . 32

Harvesting Silage Crop, Method of Cutting in Field . . 29

Harvesting Silage Crop, Necessity for Good Management. 32

Harvesting Silage Crop, Time Required to Fill Silo . . . I I, 32

Hay, Quantity Consumed when Fed with Silage . . . 12

History of System of Silage . . . . . . . . . . 5

Implements, Corn Knife . . . . . . . . . . . 29

Implements, Home Made Clod Crusher . . . . . . . 17

Implements, Rack for Handling Forage . . . . . . . . 30

Inplements, Smoothing Harrow . . . . . . . . . . 19

Implements, Wagon for Hauling Forage . . . . . . 2)

Kaffir Corn . . . . . . . . . . . . . . 25

Length of Cut of Forage .......... . 34

Listing Corn Land . . . . . . . . . . . 16

Miles, Dr. M., on Filling Silo . . . . . . . 7

Nutritive Ratio . . . . . . . . . . . 46 
Palatability of Food

Palatability, Effect on Digestion .......... . $\mathrm{I}_{3}$

Palatability, Increasing Consumption . . . . . . . . 12

Palatability of Dry Forage . . . . . . . . . . 28

Palatability of Silage . . . . . . . . 1 2,28

Rack for Hauling Silage . . . . . . . . . . . . . 30

Range Cattle Feeding . . . . . . . . . . . . 4950

Rations, Compounding. . . . . . . . . . . 48

Replanting Corn . . . . . . . . . . . I 8

Roof for Cattle Sheds . . . . . . . . . . . 57,61

Root Crops Compared with Silage . . . . . . . . . 13

Silage as an Appetizer . . . . . . . . . . . . . 12

Silage, Cattle Liking for . . . . . . . . . . . 12

Silage, Cause of Acidity . . . . . . . . . . . . . . . . 7

Silage, Cause of Decay. . . . . . . . . . . . 6,8

Silage, Composition of ... . . . . . . . . . . 24

Silage, Covering for in Silo . . . . . . . . . . . 8

Silage Crop, Hauling to Cutter . . . . . . . . . . . 3 I

Silage Crop, Implements for Harvesting . . . . . . . . 29

Silage Crop, Rack for Hauling . . . . . . . . . . . . . 30

Silage Crop, Wagon for Hauling . . . . . . . . . . . . 29

Silage, Digestibility of ..... . . . . . . . . It

Silage Feeding, Effect on Cattle ........ . I3, I4

Silage Feeding, Out from Silo . . . . . . . . . . . 44

Silage from Partially cured Forage . . . . . . . . 7

Silage from Wet Forage. . . . . . . . . . . . . 7

Silage from Uncut Forage . . . . . . . . . . . . . . . 9

Silage, Length of Cut . . . . . . . . . . . . . . . . 34

Silage, Opinions of Practical Men . . . . . . . . . Io

Silage, Overestimation of . . . . . . . . . . . . . . . 9

Silage, Quantity Cattle Eat per Day . . . . . . . . 23

Silage, Sweet and Sour . . . . . . . . . . 7, 728

Silage vs. Dry Forage. . . . . . . . . . . 9, 10

Silage, Weight of. . . . . . . . . . . . . 44

Silage, What Crops to Grow for . . . . . . . . . 14

Silo, Capacity of . . . . . . . . . . . . . . . 44

Silo, Cheap Structure . . . . . . . . . . . 4 I

Silo, Filling Slow and Fast . . . . . . . . . . 7

Silo, How to Build . . . . . . . . . . . . . 34

Silo, Material Required . . . . . . . . . . 38, 42

Silo, Method of Filling . . . . . . . . . . . 33 
Silo, Plan of ............ . . . 36, 4I

Silo, Plastered Walls . . . . . . . . . . . . . 8

Silo, Pressure Against Walls . . . . . . . . . . . . . 35

Silo, Tie Rods Across to Support Walls . . . . . . . . . 44

Silo, When First Used . . . . . . . . . . . . 5

Silo, When First Used in Gulf States . . . . . . . . . 5

Silo, Wood vs. Brick or Stone Walls . . . . . . . . . . 34

Sorghum, Certainty of Crop . . . . . . . . . . 19, 20

Sorghum, for Dry Sections and Poor Land . . . . . . 14

Sorghum, Non-Saccharine Varieties . . . . . . . . 8, 25

Sorghum, Sweet Varieties . . . . . . . . 8, 28

Sorghum, Varieties to Plant . . . . . . . . . 25

Sorghum vs. Corn Silage . . . . . . . . . . . . 15

Sorghum, When to Harvest for Silage . . . . . . . . 28

Succulent Food . . . . . . . . . . . . . . . 13

Sugar in Corn . . . . . . . . . . . . . . . 22

Sugar in Sorghum . . . . . . . . . . . . . 28

Table-Albuminoids, Carbo-Hydrates and Nutritive ratio of different Feed Stuffs . . . . . . . . . t +7

Table-Analysis of Corn Silage from several States. . 24

Table-Showing increase of Dry Matter in Corn from tasselling stage to maturity ....... . . 27

Table-Weight of Corn Fodder, Dry Matter, Sugar and Protein per acre in different Varieties of Corn in Wisconsin . . . . . . . . . . . 22

Teosinte . . . . . . . . . . . . . 25

Wild Cattle Feeding . . . . . . . . . . . . . 49, 50

Yield of Crop Grown for Silage . . . . . . 15, 22, 24, 27 
..o.. F९R SILOS ..ọ.•

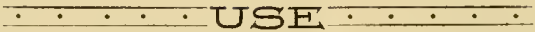

Diamond Brand Sheathing FOR LINING.

Black Diamond Roofing FOR GOVERING.

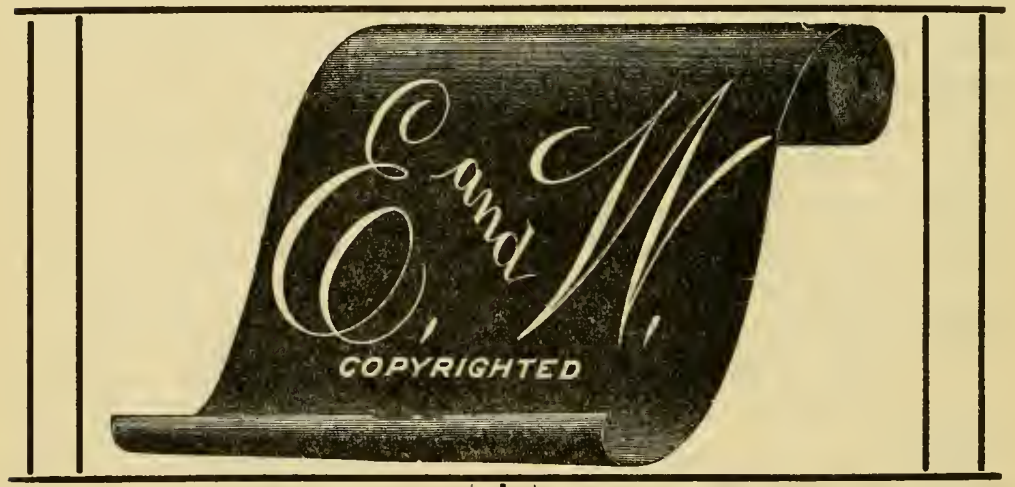

INODOROUS.

WATER-PROOF.

DAMP-PROOF.
.) FIRE-PROOF.

Put on by Anybody. Is non-conductor of Heat.

Send direct to Manufacturers for Samples, Prices and Catalogues.

Ehret- Warrę Manufacturing Go. No. I I 3 N. 8th Street, ST. LOUIS, MO. No. 16 W. MO. Av., KANSAS CITY, MO. 


\section{G. \& Ht. G.Reed \& Go.}

Marufacturers of the

\section{ORIGINHIS KHLAHMHZOO}

\section{$\rightarrow$ SPRING-N'OOWH HHRROWS}

\section{Wood and Steel Frames.}

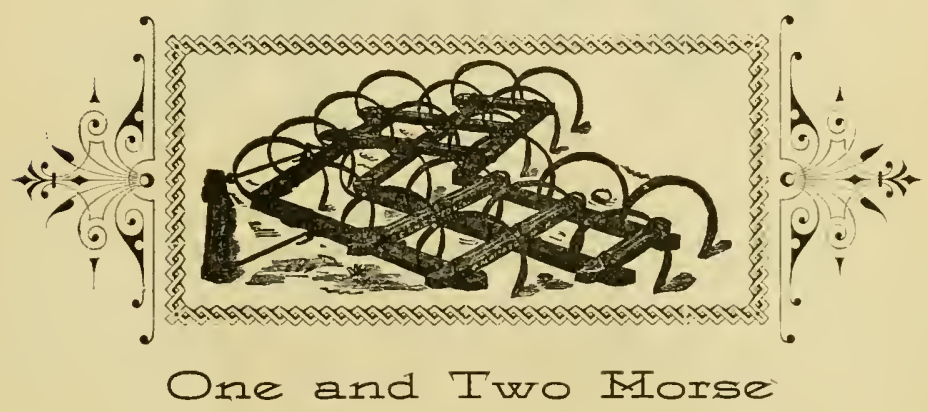

Cultivators Broad-Cast Sepders.

\section{BUY \\ @NLY

Our No. Io Riding Cultivator leads them all; as a Corn Cultivator it is a perfect success; works

$$
\text { equally as well in Cotton. }
$$

Send for Circulars.

D. G. \& H. G. Reed \& Go.n 


\section{THE BOWSHER COMBINED FEED GRINDING MLLL,}

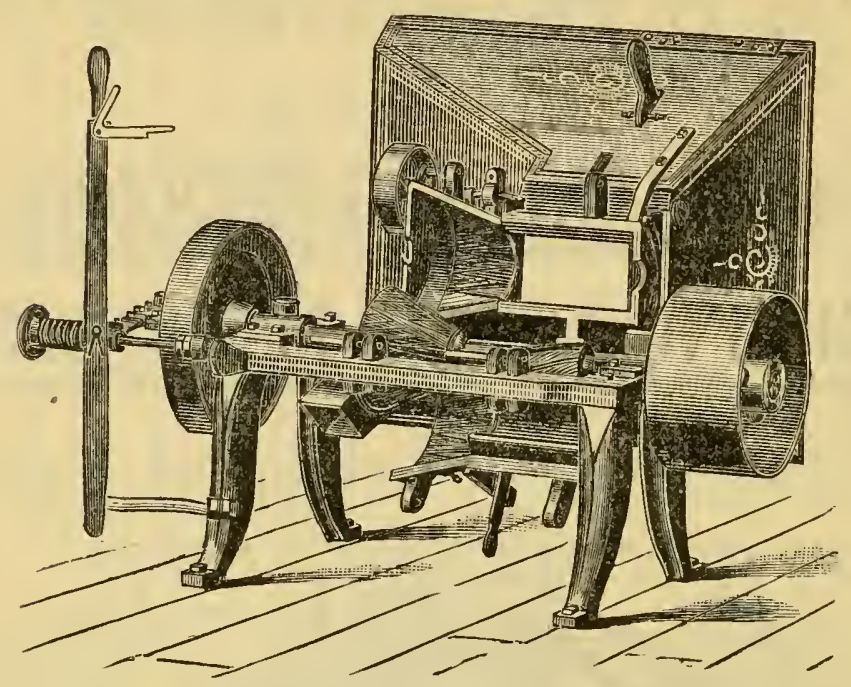

The illustration displays Bowsher's combined feed grinding mill. This is a substantially built, practical machine, novel in many respects and radically different from all other feed mills now in the market. It is supplied with the elevator attachment or without, as ordered, and is built in two sizes which require from 6 to 12 horse power, the capacity being sufficient to meet the demands of large stock raisers and those who carry on a custom milling lusiness. They crush corn with the shuck or wichout, and grind every kind of small grain, oil cake, etc., also crush corn and grind small grain at the same time, mixing the two in any proportion desired; have self-feed for ear corn and all the other conveniences which go to make a first-class, modern feed mill. The particnlar distinguishing feature of the Bowsher mill, however, is its conical shaped grinders. This cone shape makes

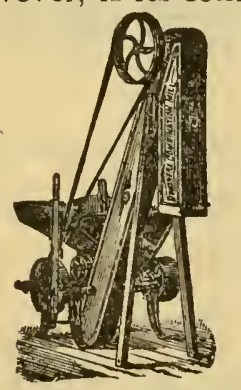

it pussible for the grinders to present a correct shearing edge to the grain at all times; a large amount of grinding surface is secured and the work is done close to the centre of the shaft, thus making an extraordiuarily light running machine. Numerous practical, labor saving - devices are also adjuncts of this mill. Pamphlet containing full information will be promptly furnished on application to

\section{H. W. HUBBARD,}

GENERAL SOUTHWESTERN MANAGER,

Atlanta, Ga., or Dallas, Texas, 


\section{4}

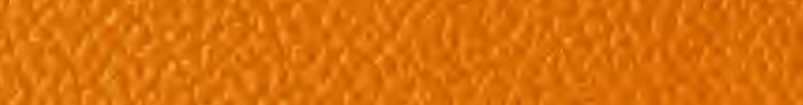

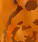

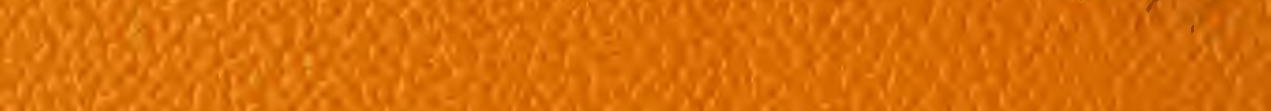
Pow

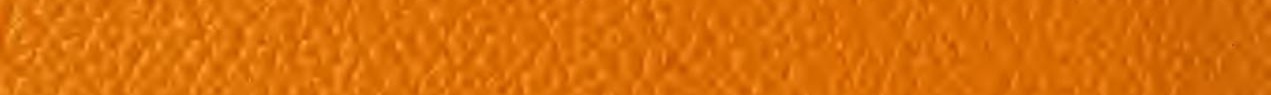

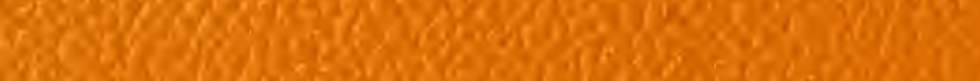

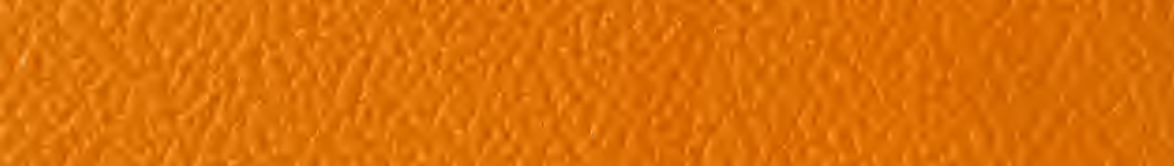

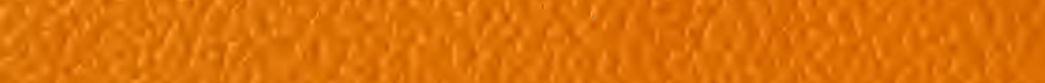

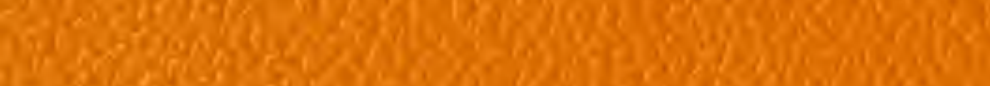

W. The

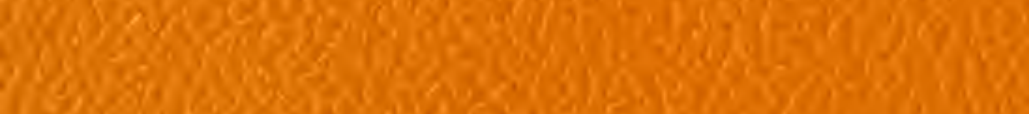

I

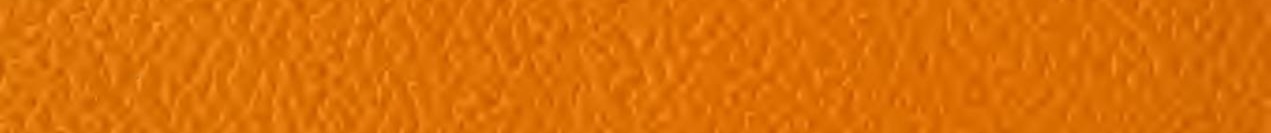

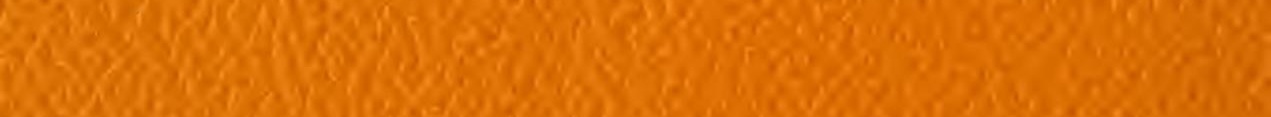

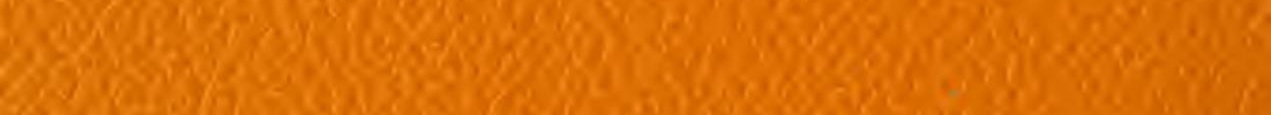

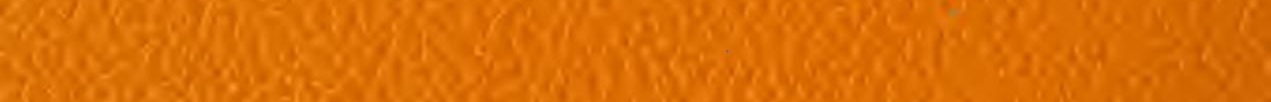

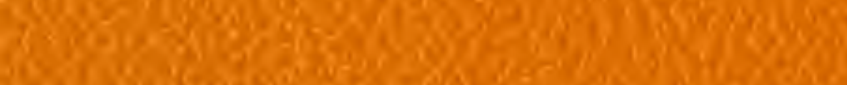

Wy

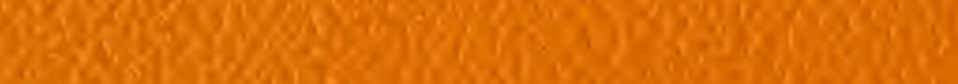

Wy

Wow

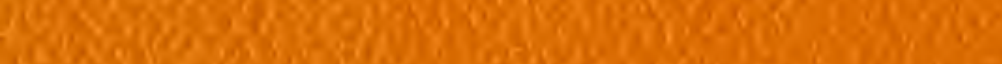

Whing

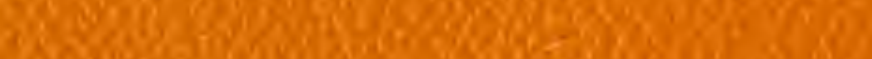

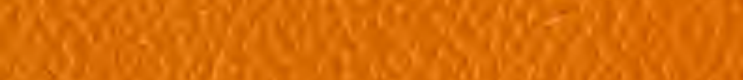

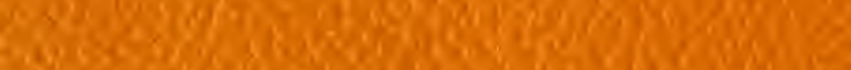

W

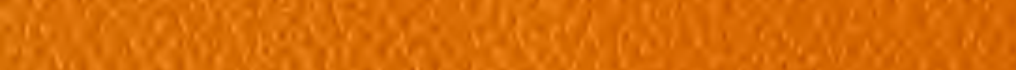

W.

Wha

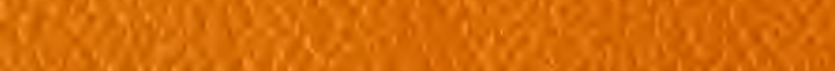

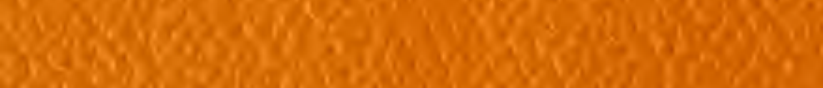

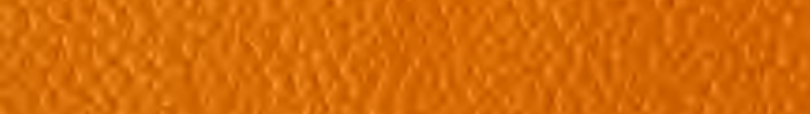

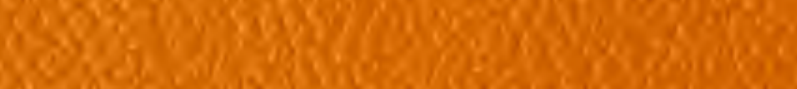

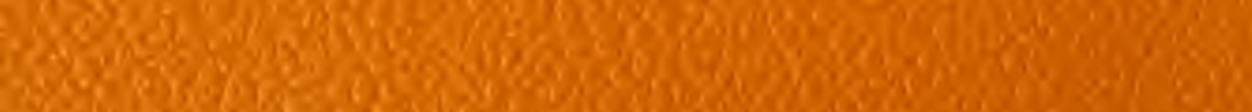

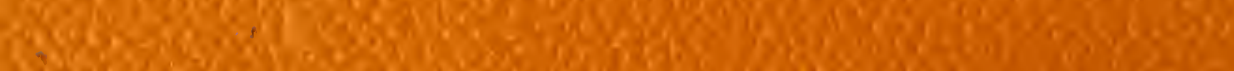

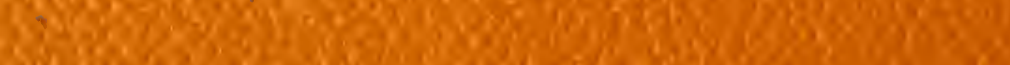

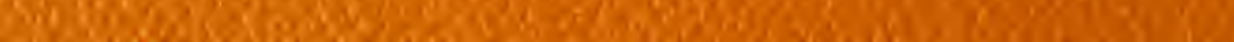




• 


